Research Article - https://doi.org/10.46463/ijrss.998601

\title{
Investigation of Leisure Time Motivation of Academic and Administrative Staff Who Do and Do not Participate in Sports Recreation Activities in Sports Facilities of the University
}

\author{
İbrahim TELCí1 $\quad$ Utku IȘIK ${ }^{2}$
}

\begin{abstract}
The aim of this study was to examine the leisure motivations of academic and administrative staff which have certain education level and regular income, and do or do not participate in sportive recreation activities in sports facilities owned by universities. The universe of the study consists of academic and administrative staff working at Recep Tayyip Erdogan University in Rize. The sample group of the study consists of 318 randomly sampled and willingly participated personnel $\left(\right.$ Mean $\left._{\mathrm{age}}=34.27 \pm 5.84\right), 176$ academics and 142 administrative personnel of Rize Recep Tayyip Erdoğan University. Personal information form and Leisure Motivation Scale were used as data collection tools. Descriptive statistics, frequency and percentage distributions were made to determine the general characteristics of the data. Mann Whitney $U$ test was used for pair comparisons and Kruskal Wallis-H test was used for group comparisons of 3 and above. Pairwise Comparisons were used to determine whether there was any significant difference between the groups following the Kruskal-Wallis- $\mathrm{H}$ test. According to the results of the analysis, no significant difference was found in the leisure motivation of the participants in terms of gender and total working years in civil service however significant differences were found in terms of marital status, job status, income, level of knowledge about sportive recreation field, utilization of sportive recreation areas, leisure time evaluation levels and weekly leisure time periods variables.
\end{abstract}

Keywords: Leisure, Motivation, Leisure Motivation

\section{Üniversitedeki Spor Tesislerinde Sportif Rekreasyon Faaliyetlerine Katılan Ve Katılmayan Akademik ve İdari Personellerin Serbest Zaman Motivasyonlarının İncelenmesi}

$\ddot{O} z$

$\mathrm{Bu}$ çalışmanın amacı; üniversitelerin sahip oldukları spor tesislerinde sportif rekreasyon faaliyetlerine katılan ve katılmayan; belirli bir eğitim seviyesi ve düzenli geliri bulunan akademik ve idari personellerin serbest zaman motivasyonlarının incelenmesidir. Çalışmanın evrenini Rize Recep Tayyip Erdoğan Üniversitesinde çalışan akademik ve idari personeller oluşturmaktadır. Çalışmanın örneklem grubunu ise rastlantısal seçilen ve çalışmada istekli olarak yer alan Rize Recep Tayyip Erdoğan Üniversitesinin, 176'sı akademik ve 142'si idari personel olmak üzere toplamda 318 personeli $\left(\right.$ Ort $_{y a s ̧}=34.27 \pm 5.84$ ) oluşturmuştur. Veri toplama aracı olarak kişisel bilgi formu ve Serbest Zaman Motivasyon Ölçeğinden faydalanılmıştır. Normal dağılıma sahip olmayan verilere ikili karşılaştırmalar için Mann Whitney U ve 3 ve üzeri grup karşılaştırmalarda ise Kruskal Wallis-H testi uygulanmıştır. Krusal-Wallis-H testinin ardından gruplar arasında herhangi bir anlamlı bir farkın bulunup bulunmadığını tespit etmek için Pairwise Comparisons karşılaştırmaları kullanılmıştır. Yapılan analizlere göre; cinsiyet ve memuriyetteki toplam çalışma yılı, serbest zaman motivasyonlarında herhangi anlamlı bir farklılık yaratmazken; medeni durum, görev durumu, gelir, sportif rekreasyon alanları hakkında ki bilgi düzeyi, sportif rekreasyon alanlarından faydalanma durumları, serbest zaman değerlendirme düzeyleri ve haftalık serbest zaman süreleri değişkenleri açısından anlamlı farklılıklara rastlanmıştır.

Anahtar Kelimeler: Serbest Zaman, Boş Zaman, Motivasyon, Serbest Zaman Motivasyonu, Boş Zaman Motivasyonu

${ }^{1}$ Recep Tayyip Erdoğan University, Faculty of Sports Sciences, Rize-TURKEY, ibrahimtelcirize@hotmail.com https://orcid.org/ 0000-0003-3458-7519

${ }^{2}$ Recep Tayyip Erdoğan University, Faculty of Sports Sciences, Rize-TURKEY, utku.isik@erdogan.edu.tr https://orcid.org/0000-0003-1877-3960 
Telci İ. \& Işık U. (2021). Investigation of Leisure Time Motivation of Academic and Administrative Staff Who Do and Do not Participate in Sports Recreation Activities in Sports Facilities of the University. International Journal of Recreation and Sport Science, 5(1); 51-62.

\section{INTRODUCTION}

In addition to the fact that the family and the social environment play an active role on the interest of the individual in physical and recreational activities, there should also be a personal desire toward these activities. Sometimes even though all the conditions are perfect, the individual may not be interested in the physical activity and sports environment. It is clear that there are many psychological and sociological reasons under this. In addition to sports scientists, researchers working in many different disciplines try to reveal the reasons why individuals do not want to be in the exercise environment from different perspectives (Sáez et al., 2021; Smith-Turchyn et al., 2021; Bender et al., 2020; Aoyagi et al., 2020; Hsu and Valentova, 2020). Studies that try to reveal these reasons are popular today and probably will remain so in the future (Iş1k et al., 2019). In both exercise psychology and social psychology of leisurestudies, motivation comes first among the concepts that clarify the behavior of individuals in the activity they participate in and its persistence. There are different theories about how individuals are motivated and on what basis their motivational source will motivate them. Motivation is shaped by the influence of individuals' expectations and needs to achieve their goals. In this context, motivation is defined as individuals acting by their own desires and making efforts in this direction (Koçel, 2015).

Motivation may be the most important of the many factors that can influence exercise and leisure experiences. Motivation is considered an integral part of the leisure experience (IsoAhola, 1979; Neulinger, 1974) and was defined as a force that initiates, directs, and sustains the behavior (Petri, 1981). In this context, leisure motivation can be defined as the energy that initiates, directs and sustains the leisure participation. Research on motivation mentions different types of motivation that lead to some certain results. Self-Determination (Will) Theory (Deci, 1980; Deci \& Ryan, 1985, 1987, 1991) is one of the most basic concepts that help us evaluate the effects of these different types of motivation on the individual. This theory argues that there are three types of motivation as intrinsic, extrinsic, and amotivation. These types of motivation are to varying degrees related to the self-will of the individual; For example, while the self-will of the individual is more dominant in intrinsic motivation, it is almost non-existent in amotivation. If the individual participates in an activity because the person enjoys it, then intrinsic motivation can be mentioned (Deci \& Ryan, 1985). The activity can be seen not as a means to some ends but as an end in itself; In this case, it can be said that the activity is extrinsically motivated (Deci \& Ryan, 1985).

Carrol and Alexandris (1997) stated that motivation is of great importance for the removal of affective and conditional obstacles to recreational participation and argued that the level of participation in recreational activities will increase with the elimination of amotivation. When the benefits that physical activities provide to the individual considered, it can be concluded that it is important not only for individual but also for public health to have the knowledge of what kind of variables are affected by the level of motivation of the individual for leisure activities and to develop strategies accordingly. In this sense, researchers have repeatedly tried to reveal by what leisure motivation is affected and how it is shaped, with many different fictional and real samples (Iso-Ahola \& Allen, 1982; Beggs \& Elkins, 2010; Dillard \& Bates, 2011; Gumus $\&$ Isik, 2018; Walker et al., 2020).

The authorities have taken great steps for the establishment of sports facilities in recent years. These steps have also shown themselves in university campuses. Sports facilities are indispensable on many university campuses. However, there are still some problems regarding the active use of the facilities built both in the city and on the campus. When individuals are asked why they do not participate in sports activities, they first mention the lack of facilities (Ekinci et al., 2014). Especially thanks to the facilities built in recent years, the problem of lack of facilities and accessibility is not a big obstacle in front of participation in sports and recreational activities. In this sense, it is important to know whether the university staff, who are educated individuals and know that doing sports is beneficial, have sufficient information about 
Telci İ. \& Işık U. (2021). Investigation of Leisure Time Motivation of Academic and Administrative Staff Who Do and Do not Participate in Sports Recreation Activities in Sports Facilities of the University. International Journal of Recreation and Sport Science, 5(1); 51-62.

the sports facilities on the campus. It is important to have information about their participation in the activities to understand the active usability of the sports areas and to develop new strategies accordingly. In addition, it is important for us to understand the differences among university personnel who are physically close to the facilities and why they are motivated to participate in sports activities, and to direct individuals who do not participate in recreational activities to these activities. In this sense, the aim of this research is to examine the leisure motivations of the academic and administrative staff who participate in sports recreation activities in the sports facilities of the university within framework of different variables.

\section{METHOD}

\section{Research Model and Protocol}

This research was conducted with the cross sectional quantitativeresearch method. The cross sectional model is a data collection method to compare and describe attitudes and behaviors (Gürsakal, 2001). Before moving on to the implementation phase of the study, the approval of individuals and institutions was obtained. The study was initiated after receiving the ethics committee report with the letter numbered 40465587-181 and protocol number 215 from the Recep Tayyip Erdoğan University Non-Interventional Clinical Research Ethics Committee. Afterwards, the scales, consisting of two parts, were taken to the academic and administrative staff specified in the sample, and the purpose and content of the study were explained, and the scales were asked to be filled in completely.

\section{Participants}

The universe of the study consisted of academic and administrative staff working at Recep Tayyip Erdogan University in Rize. The sample group of the study consisted of 318 randomly sampled and willingly participated personnel $($ Xage $=34.27 \pm 5.84), 176$ academic and 142 administrative personnel of Rize Recep Tayyip Erdoğan University who have used any of the sports facilities at least once or none at all.

\section{Data Collection Method}

The Personal Information Form and Leisure Time Motivation Scale prepared by the researchers were used to achieve the aims of the research. The data were collected in the 2019-2020 Academic Year.

Personal Information Form: The participants filled out the personal information form which give information about variables such as age, gender, marital status, administrative or academic position, title, total years in civil service, total years of work in the institution, income level, leisure time, level of knowledge about sports recreation areas, utilization of sports recreation areas, weekly leisure time, difficulties of making use of leisure time.

Leisure Time Motivation Scale: Based on the motivation theory for leisure time put forward by Pellettier et al., (1996), Deci and Ryan (1985), researchers aimed to measure the leisure motivation levels of individuals and developed a new measurement tool. The scale includes the factors that can motivate individuals to participate in recreational exercises, including "to know" (intrinsic motivation), "to accomplish" (intrinsic motivation), "to experience stimulus" (intrinsic motivation), "introjected" (extrinsic motivation), "identified" (extrinsic motivation), "externally regulated" (extrinsic motivation) and "amotivation" and a total of 28 items. The Turkish reliability and validity test of the scale were made by "Mutlu" in 2008. The Turkish version of the scale consists of 22 items and 5 sub-dimensions: "amotivation", (2) to know and to accomplish, (3) to experience stimulus, identified/introjected, and (5) "externally regulated". In this study, 5 sub-dimensions were used and the internal consistency coefficients for the sub-dimensions of the scale were found to vary between .60 and 73 . 
Telci İ. \& Işık U. (2021). Investigation of Leisure Time Motivation of Academic and Administrative Staff Who Do and Do not Participate in Sports Recreation Activities in Sports Facilities of the University. International Journal of Recreation and Sport Science, 5(1); 51-62.

\section{Analysis of the Data}

Descriptive statistics, frequency and percentage distributions were done to determine the general characteristics of the data. As statistical tests, first of all, normality tests (Kolmogorov Smirnov and Saphiro Wilk) were applied to all demographic information of the participants separately. In addition, the skewness and kurtosis coefficients of all subdimensions were examined. Both skewness and kurtosis coefficients and normality tests revealed evidence showing that the data were not normally distributed (Büyüköztürk et al., 2017). Mann Whitney U test was used for pairwise comparisons and Kruskal Wallis test was used for group comparisons with 3 and above participants. Pairwise Comparisons were used to determine if there was any significant difference between the groups following the
Krusal-Wallis-H test. The significance levels of all differences were recalculated using Bonferroni correction, and the results were reported accordingly.

\section{FINDINGS}

The sociodemographic characteristics of the sample are shown in Table 1. While $61.9 \%$ of the participants are married, $38.1 \%$ are single. $55.3 \%$ of the participants are of the academic staff. In addition, while a large proportion of the participants have information about the sports recreation areas on the campus; again, a large majority of them stated that they make use of these areas "occasionally". 
Telci İ. \& Işı1k U. (2021). Investigation of Leisure Time Motivation of Academic and Administrative Staff Who Do and Do not Participate in Sports Recreation Activities in Sports Facilities of the University. International Journal of Recreation and Sport Science, 5(1); 51-62.

Table 1. Description of the data $(n=318)$ according to some variables.

\begin{tabular}{|c|c|c|c|c|}
\hline & All $(\%)$ & Male (\%) & Female $(\%)$ & $p$-value \\
\hline \multicolumn{5}{|l|}{ Marital status } \\
\hline Married & 61.9 & 63.5 & 59.5 & \multirow{2}{*}{0.481} \\
\hline Single & 38.1 & 36.5 & 40.5 & \\
\hline \multicolumn{5}{|l|}{ Jop Status } \\
\hline Administrative & 44.7 & 46.7 & 41.3 & \multirow{2}{*}{0.349} \\
\hline Academic & 55.3 & 53.3 & 58.7 & \\
\hline \multicolumn{5}{|l|}{ Total Working Years in Civil Service } \\
\hline $1-5$ years & 36.5 & 31.0 & 45.5 & \multirow{3}{*}{0.021} \\
\hline $6-10$ years & 47.2 & 49.7 & 43.0 & \\
\hline 11 years and over & 16.4 & 19.3 & 11.6 & \\
\hline \multicolumn{5}{|l|}{ Income } \\
\hline $2501-4000$ & 13.5 & 14.2 & 12.4 & \multirow{5}{*}{.834} \\
\hline $4001-5500$ & 23.9 & 24.4 & 23.1 & \\
\hline $5501-7000$ & 35.5 & 36.5 & 33.9 & \\
\hline $7001-8500$ & 17.6 & 15.7 & 20.7 & \\
\hline 8501 and above & 9.4 & 9.1 & 9.9 & \\
\hline \multicolumn{5}{|c|}{ Knowledge About Sportive Recreation Field } \\
\hline I have information about all & 19.5 & 21.8 & 15.7 & \multirow{3}{*}{0.171} \\
\hline I have some information about & 77.4 & 74.1 & 82.6 & \\
\hline I am not aware of any & 3.1 & 4.1 & 1.7 & \\
\hline \multicolumn{5}{|l|}{ Utilization of the Fields } \\
\hline Often & 2.5 & 3.6 & 0.8 & \multirow{2}{*}{0.000} \\
\hline Sometimes & 73.0 & 82.7 & 57.0 & \\
\hline Never benefited & 24.5 & 13.7 & 42.1 & \\
\hline \multicolumn{5}{|l|}{ How Leisure Time is Used in General } \\
\hline Indoor activities & 25.2 & 17.3 & 38.0 & \multirow{4}{*}{0.000} \\
\hline Sports activities & 40.6 & 56.9 & 14.0 & \\
\hline Cultural and artistic & 14.8 & 9.6 & 23.1 & \\
\hline Activities in nature & 19.5 & 16.2 & 24.8 & \\
\hline \multicolumn{5}{|l|}{ Weekly Leisure Time } \\
\hline 10 hours and below & 11.3 & 9.6 & 14.0 & \multirow{5}{*}{0.208} \\
\hline $11-15$ hours & 7.5 & 7.6 & 7.4 & \\
\hline 16-20 hours & 10.1 & 10.2 & 9.9 & \\
\hline 21-25 hours & 46.9 & 44.2 & 51.2 & \\
\hline 26 hours or more & 24.2 & 28.4 & 17.4 & \\
\hline
\end{tabular}

${ }^{\mathrm{a} C h i}$-square test.

Table 2 shows the comparisons of the leisure motivations of the participants in terms of gender, marital status and task variables. Accordingly, no significant differences were found in the sub-dimensions of the leisure motivation scale in terms of the gender of the participants $(p>0.05)$. When we examine the marital status and the task variables, significant differences were found in the sub-dimensions except for the "amotivation" sub-dimension $(p<0.05)$. While the mean rank of the participants who are single in terms of marital status in the sub-dimensions of "experiencing stimulation", "to know-to accomplish", "identified/introjected" was significantly higher than the mean rank of the married participants; in the "externally regulated" subdimension, the mean rank of the married participants was found to be significantly higher than the mean rank of the single participants. While the mean rank of the academic staff in the sub-dimensions of 
Telci İ. \& Işık U. (2021). Investigation of Leisure Time Motivation of Academic and Administrative Staff Who Do and Do not Participate in Sports Recreation Activities in Sports Facilities of the University. International Journal of Recreation and Sport Science, 5(1); 51-62.

"experiencing stimulation", "to know-to
accomplish", "identified/introjected" was
significantly higher than the mean rank of the administrative staff; in the "externally regulated" sub-dimension, the mean rank of the administrative staff was found to be

Table 2. Mann Whitney-U Test Results

\begin{tabular}{|c|c|c|c|c|c|c|c|c|c|c|c|c|c|c|c|c|c|c|c|c|}
\hline & \multicolumn{5}{|c|}{ Experience Stimulation } & \multicolumn{4}{|c|}{ Know/Accomplish } & \multicolumn{4}{|c|}{ Identifield/Introkected } & \multicolumn{4}{|c|}{ Externally Rugulated } & \multicolumn{3}{|c|}{ Amotivation } \\
\hline & $N$ & $\begin{array}{l}\text { Mean } \\
\text { Rank }\end{array}$ & $\begin{array}{c}\text { Sum of } \\
\text { Ranks }\end{array}$ & $U$ & $p$ & $\begin{array}{l}\text { Mean } \\
\text { Rank }\end{array}$ & $\begin{array}{l}\text { Sum of } \\
\text { Ranks }\end{array}$ & $U$ & $p$ & $\begin{array}{l}\text { Mean } \\
\text { Rank }\end{array}$ & $\begin{array}{l}\text { Sum of } \\
\text { Ranks }\end{array}$ & $U$ & $p$ & $\begin{array}{l}\text { Mean } \\
\text { Rank }\end{array}$ & $\begin{array}{l}\text { Sum of } \\
\text { Ranks }\end{array}$ & $U$ & $p$ & $\begin{array}{cc}\text { Mean } & \text { Sum of } \\
\text { Rank } & \text { Ranks }\end{array}$ & $U$ & $p$ \\
\hline \multicolumn{21}{|l|}{ Gender } \\
\hline Female & 121 & 168,256 & 20359,00 & \multirow{2}{*}{10859,00} & \multirow{2}{*}{.179} & 168,03 & 20332,00 & \multirow{2}{*}{10886,00} & \multirow{2}{*}{.193} & 168,40 & 20376,50 & \multirow{2}{*}{10841,50} & \multirow{2}{*}{.175} & 168,87 & 20433,00 & \multirow{2}{*}{10785,00} & \multirow{2}{*}{.148} & $165,9220076,50$ & \multirow{2}{*}{11141,50} & \multirow{2}{*}{.315} \\
\hline Male & 197 & 154,122 & 30362,00 & & & 154,26 & 30389,00 & & & 154,03 & 30344,50 & & & 153,75 & 30288,00 & & & $155,56 \quad 30644,50$ & & \\
\hline \multicolumn{21}{|l|}{ Marital status } \\
\hline Married & 197 & 140,08 & 27595,00 & \multirow{2}{*}{8092,00} & \multirow{2}{*}{$<.0001$} & 137,54 & 27095,50 & \multirow{2}{*}{7592,50} & \multirow{2}{*}{$<.0001$} & 143,23 & 28216,00 & \multirow{2}{*}{8713,00} & \multirow{2}{*}{$<.0001$} & 167,76 & 33048,50 & \multirow{2}{*}{10291,50} & \multirow{2}{*}{.038} & $162,8932089,00$ & \multirow{2}{*}{11251,00} & \multirow{2}{*}{.388} \\
\hline Single & 121 & 191,12 & 23126,00 & & & 195,25 & 23625,50 & & & 185,99 & & & & & 17672,50 & & & $153,98 \quad 18632,00$ & & \\
\hline \multicolumn{21}{|l|}{ Jop Status } \\
\hline Administrative & 142 & 102,36 & 14535,50 & \multirow{2}{*}{4382,50} & \multirow{2}{*}{$<.0001$} & 104,09 & 14780,50 & \multirow{2}{*}{4627,50} & \multirow{2}{*}{$<.0001$} & 113,69 & 16143,50 & \multirow{2}{*}{5990,50} & $<0001$ & 192,33 & 27311,00 & 783400 & $<0001$ & $168,3123899,50$ & 1124550 & 114 \\
\hline Academic & 176 & 205,6 & 36185,50 & & & 204,21 & 35940,50 & & & 196,46 & 34577,50 & & & 133,01 & 23410,00 & 1057,00 & 80001 & $152,3926821,50$ & $112+5,00$ & .117 \\
\hline
\end{tabular}

In Table 3, the comparisons of the participants' total working time in civil service, income status, knowledge level of sportive recreation areas on campus, frequency of using sportive recreation areas, how their leisure time is generally evaluated and their leisure motivation in terms of weekly leisure time can be seen. In addition, Table 3 shows between which variables the differences occur. According to the results, no significant differences were found in terms of the total working time of the participants in civil service ( $>0.05$ ). In terms of the income status of the participants, there were significant differences in all sub-dimensions, except for the "amotivation" sub-dimension. Again, significant differences were found between the knowledge levels about sportive recreation areas and all sub-dimensions of the leisure motivation scale $(p<0.05)$. However, the difference between the groups in the two subdimensions was not reported due to Bonferroni correction. While significant differences were found between the frequency of participants' use of sportive recreation facilities and the subdimensions of "experiencing stimulation", "to know - to accomplish", "externally regulated" and "amotivation" (two subdimensions not reported due to Bonferroni correction), hence significant differences were found between how they generally make use of their leisure time and all sub-dimensions of the leisure motivation scale $(p<0.05)$. Finally, significant differences were found between the participants' weekly leisure time and all subdimensions of the leisure motivation scale $(\mathrm{p}<0.05)$. 
Telci İ. \& Işık U. (2021). Investigation of Leisure Time Motivation of Academic and Administrative Staff Who Do and Do not Participate in Sports Recreation Activities in Sports Facilities of the University. International Journal of Recreation and Sport Science, 5(1); 51-62.

Table 3. Kruskal Wallis-H Test Results

\begin{tabular}{|c|c|c|c|c|c|c|c|c|c|c|c|c|c|c|c|c|c|c|c|c|c|c|c|c|c|c|}
\hline & & \multicolumn{5}{|c|}{ Experience Stimulation } & \multicolumn{5}{|c|}{ Know/Accomplish } & \multicolumn{5}{|c|}{ Identifield/Introjected } & \multicolumn{5}{|c|}{ Externally Regulated } & \multicolumn{5}{|c|}{ Amotivation } \\
\hline & $N$ & $\begin{array}{l}\text { Mean } \\
\text { of } \\
\text { Ranks }\end{array}$ & $s d$ & $X^{2}$ & $p$ & $\begin{array}{c}\text { Pairwise } \\
\text { Com. }\end{array}$ & $\begin{array}{c}\text { Mean } \\
\text { of } \\
\text { Ranks }\end{array}$ & sd & $X^{2}$ & $p$ & $\begin{array}{c}\text { Pairwise } \\
\text { Com. }\end{array}$ & $\begin{array}{c}\text { Mean } \\
\text { of } \\
\text { Ranks }\end{array}$ & $s d$ & $x^{2}$ & $p$ & $\begin{array}{c}\text { Pairwise } \\
\text { Com. }\end{array}$ & $\begin{array}{l}\text { Mean } \\
\text { of } \\
\text { Ranks }\end{array}$ & $s d$ & $X^{2}$ & $p$ & $\begin{array}{c}\text { Pairwise } \\
\text { Com. }\end{array}$ & $\begin{array}{l}\text { Mean } \\
\text { of } \\
\text { Ranks }\end{array}$ & $s d$ & $X^{2}$ & $p$ & $\begin{array}{c}\text { Pairwise } \\
\text { Com. }\end{array}$ \\
\hline \multicolumn{27}{|l|}{ Total Working Years in Civil Service } \\
\hline $1.1-5$ Years & 116 & 171,56 & & & & & 175,48 & & & & & 163,26 & & & & & 155,31 & & & & & 154,22 & & & & \\
\hline 2. 6-10 Years & 150 & 154,08 & 2 & 3,364 & .186 & & 148,16 & 2 & 5,87 & .053 & & 156,49 & 2 & .358 & .836 & & 156,82 & 2 & 2,229 & 0.328 & & 158,88 & 2 & 1,616 & .446 & \\
\hline 3. 11 Years and Over & 52 & 148,22 & & & & & 156,57 & & & & & 159,78 & & & & & 176,58 & & & & & 173,08 & & & & \\
\hline \multicolumn{27}{|l|}{ Income } \\
\hline $1.2501-4000$ & 43 & 87,37 & & & & & 110,24 & & & & & 106,37 & & & & & 203,33 & & & & & 175,24 & & & & \\
\hline 2. $4001-5500$ & 76 & 164,51 & & & & $2>1$ & 162,82 & & & & & 156,13 & & & & 3>1 & 154,68 & & & & & 156,03 & & & & \\
\hline 3. $5501-7000$ & 113 & 162,68 & 4 & 35,71 & $<.0001$ & $3>1$ & 164,58 & 4 & 16,02 & $<.0001$ & $\begin{array}{l}3>1 \\
5>1\end{array}$ & 167,77 & 4 & 20,35 & $<.0001$ & $4>1$ & 153,17 & 4 & 13,049 & 0.011 & $1>4$ & 152,95 & 4 & 2,615 & .624 & \\
\hline $4.7001-8500$ & 56 & 181,56 & & & & $5>1$ & 167,80 & & & & & 169,91 & & & & $5>1$ & 142,02 & & & & & 158,84 & & & & \\
\hline 5.8501 and above & 30 & 197,02 & & & & & 187,03 & & & & & 193,58 & & & & & 165,35 & & & & & 171,62 & & & & \\
\hline \multicolumn{27}{|c|}{ Knowledge About Sportive Recreation Field } \\
\hline 1. I have information about all & 62 & 122,06 & & & & & 131,6 & & & & & 139,06 & & & & & 180,16 & & & & & 159,34 & & & & \\
\hline 2. I have some information about & 246 & 173,05 & 2 & 28,29 & $<.0001$ & $2>3$ & 170,92 & 2 & 23,41 & $<.0001$ & $\begin{array}{l}2>1 \\
2>3\end{array}$ & 169,28 & 2 & 21,31 & $<.0001$ & $\begin{array}{l}2>3 \\
1>3\end{array}$ & 152,38 & 2 & 7,434 & 0.024 & & 156,65 & 2 & 6,602 & 0.037 & \\
\hline 3. I am not aware of any & 10 & 58,25 & & & & & 51,55 & & & & & 45,7 & & & & & 206,45 & & & & & 230,65 & & & & \\
\hline \multicolumn{27}{|l|}{ Utilization of the Fields } \\
\hline 1. Often & 8 & 135,5 & & & & & 159,25 & & & & & 169,75 & & & & & 145,06 & & & & & 87,25 & & & & \\
\hline 2. Sometimes & 232 & 170,12 & 2 & 11,68 & .003 & $2>3$ & 167,05 & 2 & 6,237 & 0.044 & & 165,22 & 2 & 4,033 & .133 & & 150,61 & 2 & 9,855 & .007 & $2>3$ & 155,72 & 2 & 9,057 & . 011 & \\
\hline 3. Never Benefited & 78 & 130,38 & & & & & 137,08 & & & & & 141,44 & & & & & 187,42 & & & & & 178,15 & & & & \\
\hline \multicolumn{27}{|c|}{ How Leisure Time is Used in General } \\
\hline 1. Indoor activities & 80 & 103,79 & & & & & 103,15 & & & & & 116,46 & & & & & 190,29 & & & & & 192,58 & & & & \\
\hline 2. Sports activities & 129 & 188,21 & 3 & & $<000$ & $2>1$ & 184,98 & & & & $2>1$ & 178,12 & & & & $2>1$ & 126,84 & & & & $1>2$ & 138,56 & & 20601 & $<001$ & 1>2 \\
\hline 3. Cultural and artistic & 47 & 166,07 & 3 & 43,38 & $<.0001$ & $\begin{array}{l}3>1 \\
4>1\end{array}$ & 168,26 & 3 & 41,86 & $<.0001$ & $\begin{array}{l}3>1 \\
4>1\end{array}$ & 168,31 & 3 & 24,16 & $<.0001$ & $\begin{array}{l}3>1 \\
4>1\end{array}$ & 183,38 & 3 & 30,062 & $<.0001$ & $\begin{array}{l}3>2 \\
4>2\end{array}$ & 175,61 & 3 & 20,601 & $<.0001$ & $1>2$ \\
\hline 4. Activities in nature & 62 & 166,65 & & & & & 172,56 & & & & & 169,61 & & & & & 169,61 & & & & & 148,19 & & & & \\
\hline \multicolumn{27}{|l|}{ Weekly Leisure Time } \\
\hline 1.10 hours and below & 36 & 108,31 & & & & $4>1$ & 132,13 & & & & & 132,13 & & & & & 211,39 & & & & $1>4$ & 185,78 & & & & \\
\hline 2. 11-15 hours & 24 & 105,13 & & & & $4>2$ & 147,17 & & & & $4>3$ & 147,17 & & & & & 240,63 & & & & $1>5$ & 166,13 & & & & \\
\hline 3. $16-20$ hours & 32 & 82,52 & 4 & 59,85 & $<.0001$ & $4>3$ & 104,22 & 4 & 48,13 & $<.0001$ & $5>3$ & 104,22 & 4 & 20,31 & $<.0001$ & $4>3$ & 226,11 & 4 & 67,779 & $<.0001$ & $2>4$ & 203,08 & 4 & 14,787 & $<.0001$ & $3>5$ \\
\hline 4. $21-25$ hours & 149 & 182,12 & & & & (5) 301 & 171,55 & & & & $5>1$ & 171,55 & & & & & 130,78 & & & & $2>3$ & 151,29 & & & & \\
\hline 5. 26 hours or more & 77 & 188,6 & & & & $5>3$ & 175,81 & & & & & 175,81 & & & & & 137,85 & & & & $3>5$ & 142,93 & & & & \\
\hline
\end{tabular}

\section{DISCUSSION AND CONCLUSION}

In this study, in which the leisure motivations of university personnel with similar education and socio-economic levels and who do not have any handicaps in accessing sportive recreation facilities were compared in terms of different variables, it was concluded that the different characteristics of the participants made a difference on their leisure motivation.

According to the results of the analyses, although there was no significant difference in all sub-dimensions in terms of gender variable, it was seen that male participants got higher scores. In the literature, it is possible to come across studies in which both women and men outperform each other in terms of leisure motivation averages, as well as studies that did not find any differences. Fortier et al. (1995) also found that women's achievement scores were higher than men's, and that amotivation was higher in men. In the study of Kaya (2003), the lack of motivation of men was found to be statistically significantly higher than that of women. In a study of Mutlu (2008), the amotivation of women was found to be higher than that of men. In a different study by Altunay and Balcı (2018), it was found statistically significant that females were more motivated than males in four of the five sub-dimensions in the leisure motivation scale, excluding the "externally regulated" dimension. It has been revealed that the motivation of men only in the "externally regulated" dimension are higher than that of women. The fact that there was no significant difference between male and female participants in our study may be due to the fact that the education levels of university employees are close to each other. Besides male academics, female academics tend to spend their lesiure time actively. It is an expected situation that there will not be any difference between male and female participants in social environments where the education level is close to each other and the socio-cultural structure is similar.

Significant differences surfaced in the subdimensions of "experience stimulation", "identified-introjected", "to know and to accomplish", and "externally regulated" in terms of the marital status variable. In similar 
Telci İ. \& Işık U. (2021). Investigation of Leisure Time Motivation of Academic and Administrative Staff Who Do and Do not Participate in Sports Recreation Activities in Sports Facilities of the University. International Journal of Recreation and Sport Science, 5(1); 51-62.

studies, Mutlu et al., (2011) showed us that single participants had higher scores in the "externally regulated" sub-dimension compared to marital status. In a study conducted on teachers, no significant differences were found in terms of marital status (Altunay \& Balc1, 2018). The priority of married individuals seems like their families. However, single participants have much more leisure time than married participants and may be more easily motivated to use this leisure time actively. Since married participants spend their leisure time mostly with their families and children, and this is generally not seen as a leisure time activity, it is a natural result that married participants have a high level of amotivation.

There were significant differences in all subdimensions, except for the "amotivation" subdimension, according to the Civil Service variable. In the sub-dimensions of "experience stimulation", "identified-introjected", "to know and to accomplish", academic staff scored significantly higher; in the "externally regulated" sub-dimension, administrative personnel achieved significantly higher scores. There are differences between academic and administrative staff in terms of income level. Average monthly income of academic staff is higher than average monthly income of administrative staff. Considering this, it is expected that individuals with higher incomes have higher leisure motivation levels. Indeed, in a study conducted by Tarcan (2019), participants with higher incomes had higher averages in the sub-dimension of "to know" compared to participants with lower incomes; it has been observed that individuals with low income have a higher rate of "externally regulated" motivation than individuals with high income.

According to the variable of total working time in civil service, no significant difference was found in the leisure motivation of the participants. In Öztaş (2018)'s study, no significant difference was found between the leisure time satisfaction of civil servants working in different institutions in terms of working years in their institutions. In a different study conducted by Y1ld1z (2018) with the personnel of the police department, no significant difference was found between the years of seniority and leisure time attitudes of the participants. As the professional years and experience of individuals entering public institutions and organizations increase, there is no difference in their leisure preferences and leisure motivations. Individuals working in public institutions, whether experienced or less experienced, participate in leisure time activities in a similar way. Although there are differences between individuals in different positions, the working years in the public sector do not affect the leisure time motivation.

According to the Income Status variable; There are significant differences in the subdimensions of "experience stimulation", "identified-introjected", "to know and to accomplish" as income increases. In the "amotivation" sub-dimension, it is seen that the average of the participants with low income is higher. In similar studies conducted by Binarbaş1 (2006), in a study on teachers in Kütahya, it was stated that teachers did not see their economic situation as the reason for not being able to participate in leisure time activities sufficiently. In the study conducted by Ardahan and Lapa (2010), it was observed that as the income levels of the participants increased, their satisfaction levels in such activities also increased. According to a research conducted by Mutlu et al., (2011) it has been concluded that individuals with lower income levels have higher amotivation and "externally regulated" scores. Depending on the results, income significantly affects both the leisure preferences of the participants, the frequency of their participation in leisure time activities, and therefore their leisure motivation. The higher the income, the more individuals can self-motivate to participate in leisure time activities.

According to the variable of the knowledge level of the participants about the sportive recreation facilities; While a significant difference was detected in all sub-dimensions, the participants who marked the "I have knowledge about some of them" group in the sub-dimensions of "experience stimulation", "identified-introjected", "to know and to accomplish"; On the other hand, in the subdimension of "externally regulated" and 
Telci İ. \& Işık U. (2021). Investigation of Leisure Time Motivation of Academic and Administrative Staff Who Do and Do not Participate in Sports Recreation Activities in Sports Facilities of the University. International Journal of Recreation and Sport Science, 5(1); 51-62.

"amotivation", it was seen that the participants in the "I am not aware" group scored higher. The common point revealed in many studies investigating the factors that prevent participation in leisure time activities is the limited knowledge level of the participants about the facilities and the inadequacy of the facilities (Arslan et al., 2018; Tekin et al., 2006; Öz and Ardahan, 2019; Turan et al., 2019). It is expected that the motivation of those who are not aware of the existence of facilities where they can perform recreational activities is low in terms of participation in recreational activities. However, there are some facilities, although not enough, both in the city and on the campus to spend leisure time. It is clear that being aware of these places will motivate individuals to use them. As a matter of fact, the motivation of the individuals who have knowledge about the facilities is higher than the participants who are not aware at all. It can be concluded that the more frequently individuals are informed about the facilities, the more they will use the facilities.

According to the variable of the participants' use of sportive recreation areas; significant differences emerged between leisure time motivations. According to the variable, it has been shown that the individuals who do not benefit from the sportive recreation facilities have a high level of amotivation, and the motivation of the individuals who make use of them is higher. In the study conducted by Güngörmüş et al., (2018), it was determined that individuals who participate more in physical activity have higher leisure satisfaction, life satisfaction and perceived freedom in leisure time. In addition, in a different study conducted by Öztaş (2018), leisure satisfaction increases as participation in leisure activities increases. According to the study of Iş1k and Güngörmüş (2018), positive changes occur in psychological well-being as participation in leisure time activities increases. If there is no participation in leisure time activities, there will be no motivation at the point of participation in leisure time activity. Participation of individuals in leisure time activities is realized thanks to the motivation they feel, and this creates increase in life satisfaction, leisure satisfaction, psychological well-being, and perceived freedom. In this sense, the motivation individuals feel for activities is a prerequisite for participation in recreational activities. When this condition is fulfilled, the abovementioned positive psychological effects may occur in the individual.

According to the variable of making use of the leisure time of the participants; While a significant difference was detected in all subdimensions, the averages of the group participating in sports activities in the subdimensions of "experience stimulation", "identified-introjected", "to know and to accomplish"; on the other hand, in the subdimension of "externally regulated" and "amotivation", the averages of the group engaged in domestic activities were found to be higher. In their study, Yerlisu et al., (2012) revealed significant differences in the leisure time motivations of the participants doing sports activities; it was seen that individuals who participated in more passive activities had higher amotivation scores. In a different study by Lapa and Ağyar (2012), it was determined that the level of freedom felt by the participants who actively participate in sports activities in their leisure time participation is higher than that of passive participators. Depending on these results, it can be said that sportive activities are found much more satisfying than other activities and that they motivate individuals much more to participate. Individuals incline to participate in sports activities more than they do other activities. Leisure time motivation achieves high averages when it comes to sports activities.

According to the variable of the participants' weekly leisure time; While a significant difference was found in all sub-dimensions, the participants who formed the 26+ hours group in the sub-dimensions of "experience stimulation", "identified-introjected", "to know and to accomplish"; In the sub-dimension of "externally regulated" and "amotivation", it was seen that the participants in the 16-20 hour group had higher averages. In the study conducted by Yerlisu et al., (2012), it was determined that the leisure motivation scores of the participants and the frequency of participation in activities showed a difference 
Telci İ. \& Işık U. (2021). Investigation of Leisure Time Motivation of Academic and Administrative Staff Who Do and Do not Participate in Sports Recreation Activities in Sports Facilities of the University. International Journal of Recreation and Sport Science, 5(1); 51-62.

on the leisure motivation of individuals. In a different study conducted by Üstün (2013), the motivation of the sample group to participate in recreational activities was affected by the weekly leisure time they had, and it was seen that the participants who had more leisure time were more easily motivated. In the study of Güngörmüş et al., (2018), as the weekly leisure time increases, participation in the leisure time activity levels also increase. In the study conducted by Öztaş (2018), it was found that as the weekly leisure time increased, the leisure time satisfaction of the participants increased. The individual participates in leisure time activities in his spare time from work and other responsibilities. Considering this situation, it is clear that the more leisure time an individual has, the more leisure time activities he will participate in and the more motivated he will be to participate.

\section{Recommendations}

Active participation in leisure time contributes significantly to the individual's happiness, life satisfaction, and psychological well-being. In this sense, it is very important to be motivated towards leisure time activities, which is the prerequisite for participation. Within the scope of this study, the leisure time motivations of the participants whose education level is above a certain level and who have a regular income were tried to be examined.

According to these results it can be concluded that:

1) In order to increase the motivation of the academic and administrative staff at the university to participate in leisure time activities, they can cooperate with other public institutions and businesses, and support them in facilitating the participation of the staff in leisure time and leisure education,

2) Universities can be encouraged to increase the number of facilities and clubs where academic and administrative staff can spend their leisure time,

3) University staff can be informed about the facilities around,

4) Courses on leisure time activities can be organized for the university staff,
5) The fact that sportive activities are much more effective and beneficial than other leisure activities can be conveyed to university personnel through educational events.

6) To expand the universe and sample of the study, more academic and administrative staff can be included in the study.

7) Comparative studies can be conducted with personnel working at other universities.

\section{REFERENCES}

Abadan, N. (1961). Türk üniversite öğrencilerinin serbest zaman faaliyeti, boş zamanları değerlendirme semineri. Halk Sağllğı Eğitim Komitesi Yayını, İstanbul.

Altunay, B. R., Balc1, V. (2018). Ankara ili Keçiören ilçesindeki ilköğretim okullarında görev yapan öğretmenlerin boş zaman etkinliklerine katılım motivasyonu, Spor ve Performans Araştırmaları, Dergisi, DOI: 10.17155/Omuspd.412516.

Aoyagi, K., Ishii, K., Shibata, A., Arai, H., Fukamachi, H., \& Oka, K. (2020). A qualitative investigation of the factors perceived to influence student motivation for school-based extracurricular sports participation in Japan. International Journal of Adolescence and Youth, 25(1), 624-637.

Ardahan. F., ve Lapa, T. Y. (2010). Üniversite öğrencilerinin serbest zaman tatmin düzeylerinin cinsiyete ve gelire göre incelenmesi. Spor Bilimleri Dergisi, 21(4), 129-136.

Arslan, E., Namll. A. Y., \& Doğaner, S. (2018). Üniversite öğrencileri neden aktif değiller? katılımsal engeller. Spormetre Beden Eğitimi ve Spor Bilimleri Dergisi, 16(4), 140-150.

Beggs, B. A., \& Elkins, D. J. (2010). The influence of leisure motivation on leisure satisfaction. LARNet-The Cyber Journal of Applied Leisure and Recreation Research, (July).

Bender, A. A., Halpin, S. N., Kemp, C. L., \& Perkins, M. M. (2021). Barriers and facilitators to exercise participation among frail older African American assisted living residents. Journal of Applied Gerontology, 40(3), 268-277.

Binarbaşı, S. (2006). İlköğretim okullarında görev yapan öğretmenlerin boş zamanlarını değerlendirme alışkanlıklarının tespiti ve incelenmesi, Yüksek Lisans Tezi, Kütahya. 
Telci İ. \& Işık U. (2021). Investigation of Leisure Time Motivation of Academic and Administrative Staff Who Do and Do not Participate in Sports Recreation Activities in Sports Facilities of the University. International Journal of Recreation and Sport Science, 5(1); 51-62.

Büyüköztürk, Ş., Çakmak, E. K., Akgün, Ö. E., Karadeniz, Ş., \& Demirel, F. (2017). Bilimsel araştırma yöntemleri. Pegem Atıf Indeksi, 2017, 1-360.

Can, E., \& Gök, S. (2003). Bir rekreasyon faaliyeti olarak-üniversitelerarası müsabakalara katılan sporcu öğrencilerin liderlik davranışlarının (anlayış gösterme boyutunda) karşıllaştırılması. Spor Yönetimi ve Bilgi Teknolojileri, 2(1), 23-30.

Deci, E. L., Ryan, R. M. (1985). Intrinsic motivation and self-determination in human behaviour. new york plenum, [AKT: The general causality orientations scale: Self-determination in personality. Journal of Research in Personality. Volume 19, Issue 2, June 1985, Pages 109134.

Deci, E. L., Ryan, R. M. (1991). A motivational approach to self integration in personality. nebraska symposium on motivation. University Of Nebraska Pres, Lincoln.

Dillard, J. E., \& Bates, D. L. (2011). Leisure motivation revisited: why people recreate. Managing Leisure, 16(4), 253268.

Ekinci, N. E., Kalkavan, A., Üstün, Ü. D., \& Gündüz, B. (2014). Üniversite ögrencilerinin sportif ve sportif olmayan rekreatif etkinliklere katılmalarına engel olabilecek unsurların incelenmesi. Sportif Bakış: Spor ve Eğitim Bilimleri Dergisi, 1(1), 1-13

Fortier, M. S., Vallerand, R. J., Briere, N. M., Provencher, P. J. (1995). Competitive and recreational sport structures and gender: A test of their relationship with sport motivation. International Journal of Sport Psychology, 26, 24-39.

Gumus, H., \& Isik, O. (2018). The relationship of physical activity level, leisure motivation and quality of life in candidate teachers. International Journal of Progressive Education, 14(5), 22-32.

Güngörmüş, H. A., Işı1k, U., Demirdöğen, S. (2018). Dans okullarına üye bireylerin serbest zaman ilgilenim düzeyleri ile psikolojik iyi oluş ilişkisi. 16. Uluslararası Spor Bilimleri Kongresi. Antalya. 1520-1529.

Güngörmüş, H. A., Serdar, E., Beşikçi, T., \& Dirilik, Y. (2018). "Fitness merkezlerinden hizmet alan bireylerin serbest zaman doyumu ve psikolojik iyi oluş ilişkisi," Uluslararası Rekreasyon ve Spor Yönetimi Kongresi, Bildiriler Kitapçı̆̆ $\breve{l}, 10-13$ Mayıs, Bodrum/Muğla, 425-426.

Hsu, R. M. C. S., \& Valentova, J. V. (2020). Motivation for different physical activities: a comparison among sports, exercises, and body/movement practices1. Universidade de São Paulo, Instituto de Psicologia, Department of Experimental Psychology, São Paulo, Brazil. Psicologia USP, Volume 31, e190153. 1-10.

Iso-Ahola, S. E., \& Allen, J. R. (1982). The dynamics of leisure motivation: The effects of outcome on leisure needs. Research Quarterly for Exercise and Sport, 53(2), 141-149.

Iş1k, U. (2018). How to be a serious leisure participant? (a case study). Journal of Education and Training Studies, 6(9), 146151.

Işık, U., ve Üstün, Ü. D. (2019). Boş zamanları değerlendirmede güncel konular. Son çă̆ Matbaacılık, 978-605-258-775-1

Işı1k, U., ve Güngörmüş, H. A. (2018). Rekreasyonel amaçlı kayak yapan bireylerde serbest zaman doyumu ve psikolojik iyi oluş. 16. Uluslararası Spor Bilimleri Kongresi. Antalya. 1530-1539.

Işık, U., Görgülü, R., \& Tok, S. (2019). Spor ve egzersiz psikolojisinde gelecek yillardaki muhtemel değişimler. Presented At The 17th International Sport Sciences Congre.

Kaya, S. (2003). Yetiştirme yurtlarında kalan gençlerin boş zaman değerlendirme eğilimi ve etkinliklerin sosyalleşmeye etkisi, Doktora Tezi. Gazi Üniversitesi, Sağlık Bilimleri Enstitüsü, Beden Eğitimi ve Spor Anabilim Dalı, Ankara.

Kılıç, M. \& Öztürk, E. (2011). Yükseköğretim çerçevesinde öğrenci konseylerinin fonksiyonalist-çatışmacı yaklaşımlar açısından değerlendirilmesi. Uluslararası Yükseköğretim Kongresi: Yeni Yönelişler ve Sorunlar (UYK-2011), 3(14), 2097 2103.

Kocaekşi, S. (2012). Boş Zaman ve rekreasyon yönetimi. (Ed.), Eskişehir: Anadolu Üniversitesi Yayını, No: 2497, Açıkögrretim Fakültesi Yayını No: 1468, Mayıs.

Lapa, T. Y., \& Ağyar, E. (2012). Üniversite öğrencilerinin serbest zaman katılımlarına göre algılanan özgürlük. Spor Bilimleri Dergisi, 23(1), 24-33.

McLean, D. D., Hurd, A. R., \& Rogers, N., B. (2005). Leisure and recreation in modern society. Johns and Bartlett Publishers. Massachusetts.

Mutlu, İ. (2008). Egzersiz yapan kişilerin boş zamanlarına yönelik tutumları üzerine bir araştırma (Kayseri İli Örneği), Yayınlanmamış Yüksek Lisans Tezi, Niğde Üniversitesi Sosyal Bilimler Enstitüsü. 
Telci İ. \& Işık U. (2021). Investigation of Leisure Time Motivation of Academic and Administrative Staff Who Do and Do not Participate in Sports Recreation Activities in Sports Facilities of the University. International Journal of Recreation and Sport Science, 5(1); 51-62.

Mutlu. İ., Yılmaz, B., Sevindi, T., Göngörmüş, H. A., Gürbüz, B. (2011). Bireyleri rekreasyonel amaçlı egzersize motive eden faktörlerin çeşitli değişkenlere göre karşılaştırılması. Selçuk Üniversitesi. Beden Eğitimi ve Spor Bilim Dergisi, 13 (1), 54-61.

Öz, N. D., \& Ardahan, F. (2019). Köyde rekreasyon engelleri ölçeği geçerlilik ve güvenirlilik çalışması. Mediterranean Journal of Humanities, 9(1), 141-151.

Özdağ, S. (1996). Yerel yönetimlerde (belediyelerde) rekreatif etkinliklerin yeri ve önemi. Yüksek Lisans Tezi, Gazi Üniversitesi, Sağlık Bilimleri Enstitüsü, Ankara, s:131.

Öztaş, İ. (2018). Farklı kurumlarda çalışan memurların serbest zaman doyum ve mutluluk düzeylerinin belirlenmesi (Kırıkkale ili örneği) (Master's thesis, Ağr1 İbrahim Çeçen Üniversitesi, Sosyal Bilimler Enstitüsü).

Pelletier, L. G., Vallerand, R. J., Blais, M. R., Brière, M. N. (1991). Leisure Motivation Scale (LMS-28). [Online Erişim Adresi: http://www.er.uqam.ca/nobel/r26710/LRCS / echelles/EML28_en.pdf].

Pelletier, L. G., Vallerand, R. J., Demers, G. I., Blais, M. R., Brière, M. N. (1996). Vers une conceptualisation motivationnelle nultidimensionnelle du loisir: construction et validation de lechelle de motivation vis a vis des lousirs (eml). Society and Leisure, 19(2), 559-585.

Sáez, I., Solabarrieta, J., \& Rubio, I. (2021). Motivation for physical activity in university students and its relation with gender, Amount of activities, and sport satisfaction. Sustainability, 13(6), 3183.

Smith-Turchyn, J., Allen, L., Dart, J., Lavigne, D., Rooprai, S., Dempster, H., \& Adams, S. C. (2021). Characterizing the exercise behaviour, preferences, barriers, and facilitators of cancer survivors in a rural canadian community: A cross-sectional survey. Current Oncology, 28(4), 31723187.

Tekin, A., Tekin, G., Amman, M. T. (2006). Serbest zamanlarda yapılan fiziksel egzersizin üniversite öğrencilerinin depresyon ve atılganlık düzeylerine etkisi. 9. Uluslararası Spor Bilimleri Kongresi Bildiri Kitapçığı, 19-23, Muğla.

Tolukan, E., (2010). Özel yetenekle ilgili bölümlerde okuyan üniversite öğrencilerinin rekreasyonel aktivitelere katılımlarına engel olabilecek unsurların belirlenmesi. Niğde Üniversitesi, Sosyal Bilimler Enstitüsü. (Yayınlanmamıı̧ Yüksek Lisans Tezi) Niğde.

Turan, E. B., Gülșen, D. B. A., Bilaloğlu, M. (2019). Kadın Çalışanların Yaşam Doyumu Ile Boş Zaman Engelleri Arasındaki Ilişki: Akdeniz Üniversitesi Örneği. Gaziantep Üniversitesi, Spor Bilimleri Dergisi. 4(1), s: 104-114.

Üstün, Ü. D., Kalkavan, A., Demirel, M. (2013). Investigating free time motivation scores of physical education and faculty of education students according to different variables. TOJRAS 2 (1).

Walker, G. J., Yan, N., \& Kono, S. (2020). Basic psychological need satisfaction and intrinsic motivation during leisure: A crosscultural comparison. Journal of Leisure Research, 51(4), 489-510.

Yerlisu, L. T., Ağyar, E., \& Bahadır, Z. (2012). Yaşam tatmini, serbest zaman motivasyonu, serbest zaman katılımı: Beden eğitimi ve spor öğretmenleri üzerine bir inceleme (Kayseri ili örneği). Spormetre Beden Eğitimi ve Spor Bilimleri Dergisi, 10(2), 53-59.

Yildı, R. (2018). Rekreasyonel aktivitelere katılım durumuna göre bel ve/veya sırt ağrısı çeken bireylerin fizik tedavi alma sıklıkları: Batman ili örneği (Master's thesis, Batman Üniversitesi). 
Research Article - https://doi.org/10.46463/ijrss.998601

\section{Üniversitedeki Spor Tesislerinde Sportif Rekreasyon Faaliyetlerine Katılan ve Katılmayan Akademik ve İdari Personellerin Serbest Zaman Motivasyonlarının İncelenmesi}

\section{$\ddot{\partial} z$}

$\mathrm{Bu}$ çalışmanın amacı; üniversitelerin sahip oldukları spor tesislerinde sportif rekreasyon faaliyetlerine katılan ve katılmayan; belirli bir eğitim seviyesi ve düzenli geliri bulunan akademik ve idari personellerin serbest zaman motivasyonlarının incelenmesidir. Çalışmanın evrenini Rize Recep Tayyip Erdoğan Üniversitesinde çalışan akademik ve idari personeller oluşturmaktadır. Çalışmanın örneklem grubunu ise rastlantısal seçilen ve çalışmada istekli olarak yer alan Rize Recep Tayyip Erdoğan Üniversitesinin, 176'sı akademik ve 142'si idari personel olmak üzere toplamda 318 personeli $(X y a s ̧=34.27 \pm 5.84)$ oluşturmuştur. Veri toplama aracı olarak kişisel bilgi formu ve Serbest Zaman Motivasyon Ölçeğinden faydalanılmıştır. Normal dağılıma sahip olmayan verilere ikili karşılaştırmalar için Mann Whitney U ve 3 ve üzeri grup karşılaştırmalarda ise Kruskal Wallis-H testi uygulanmıştır. Krusal-Wallis-H testinin ardından gruplar arasında herhangi bir anlamlı bir farkın bulunup bulunmadığını tespit etmek için Pairwise Comparisons karşılaştırmaları kullanılmıştır. Yapılan analizlere göre; cinsiyet ve memuriyetteki toplam çalışma yılı, serbest zaman motivasyonlarında herhangi anlamlı bir farklılık yaratmazken; medeni durum, görev durumu, gelir, sportif rekreasyon alanları hakkında ki bilgi düzeyi, sportif rekreasyon alanlarından faydalanma durumları, serbest zaman değerlendirme düzeyleri ve serbest zaman süreleri değişkenleri açısından anlamlı farklılıklara rastlanmıştır.

Anahtar Kelimeler: Serbest Zaman, Boş Zaman, Motivasyon, Serbest Zaman Motivasyonu, Boş Zaman Motivasyonu

\section{GİRIŞ}

Bireyin fiziksel ve rekreatif etkinliklere yönelmesinde aile ve çevrenin etkin bir rol oynamasının yanı sıra bu etkinliklere yönelme ile ilgili kişisel bir isteğinin da bulunması gerekmektedir. Bütün şartlar mükemmel olmasına rağmen birey bazen fiziksel etkinlik veya spor ortamının içerisinde bulunmak istemez. Bunun birçok psikolojik ve sosyolojik nedeninin bulunduğu açıktır. Spor bilimcilerin yanı sıra birçok farklı bilim dalında çalışan araştırmacılar bireylerin egzersiz ortamında bulunmak istememelerinin nedenlerini farklı bakış açılarıyla ortaya koymaya çalışmaktadırlar (Sáez ve ark.,2021; SmithTurchyn ve ark.,2021; Bender ve ark.,2020; Aoyagi ve ark.,2020; Hsu ve Valentova,2020). $\mathrm{Bu}$ nedenleri anlamaya çalışan araştırmalar, geçmişte olduğu gibi günümüzde ve muhtemelen gelecekte de popülerliğini koruyacaktır (Iş̧k ve ark.,2019).
Hem egzersiz psikolojisinde hem de rekreasyon çalışmalarında bireylerin katılım sağladıkları aktivite içerisindeki sergiledikleri davranışları ve devamlılıklarının nasıl gerçekleşeceği konusuna açılık getiren kavramların başında motivasyon gelmektedir. Bireylerin nasıl motive oldukları, motivasyon kaynaklarının hangi temele dayanarak onları harekete geçireceğine dair farklı motivasyon teorileri bulunmaktadır. Motivasyon, bireylerin hedeflerine ulaşmak için beklentilerinin ve ihtiyaçlarının yönlendirmesi ile şekillenmektedir. $\mathrm{Bu}$ bağlamda motivasyon, bireylerin kendi arzu ve istekleri ile davranmaları ve bu doğrultuda çaba göstermeleri şeklinde tanımlanmaktadır (Koçel, 2015).

Egzersiz ve serbest zaman deneyimlerini etkileyebilecek birçok faktör arasında motivasyon en önemlisi olabilir. Motivasyon, serbest zaman deneyiminin ayrilmaz bir parçası olarak kabul edilir (Iso-Ahola, 1979; Neulinger, 1974) ve davranışı başlatan, 
Telci İ. \& Işık U. (2021). Investigation of Leisure Time Motivation of Academic and Administrative Staff Who Do and Do not Participate in Sports Recreation Activities in Sports Facilities of the University. International Journal of Recreation and Sport Science, 5(1); 51-62.

yönlendiren ve sürdüren bir güç olarak tanımlanır (Petri, 1981). Bu bağlamda serbest zaman motivasyonu, serbest zaman katılımını başlatan, yönlendiren ve sürdüren enerji olarak ifade edilebilir. Motivasyonla ile ilgili araştırmalar, belirli sonuçlara yol açan farklı motivasyon türlerinden bahsetmektedir. ÖzBelirleme (İrade) Kuramı (Deci, 1980; Deci ve Ryan, 1985, 1987, 1991), bu farkl1 motivasyon türlerinin bireydeki etkilerini değerlendirmemizde bize yardımcı olan en temel kurumların başında gelir. $\mathrm{Bu}$ teori, üç geniş motivasyon türü olduğunu savunur: içsel, dişsal ve motivasyonsuzluk. $\mathrm{Bu}$ motivasyon türleri değişen derecelerde bireyin öz iradesi ile ilgilidir; örneğin içsel motivasyonda bireyin öz-iradesi daha baskınken, motivasyonsuzlukta yok denecek kadar azdır. Birey bir aktiviteye katıldığında ondan zevk aldığı için katılım sağliyorsa, bu durumda içsel motivasyondan bahsedilebilir (Deci ve Ryan, 1985). Faaliyet, bazı amaçlara yönelik bir araç olarak değil, kendi içinde bir amaç olarak da görülebilir; bu durumda, faaliyetin dişsal olarak motive edildiği söylenebilir (Deci ve Ryan, 1985).

Carrol ve Alexandris (1997) rekreatif katılımın önündeki engellerin kalkması için motivasyonun çok büyük önemi olduğunu belirtmiştir ve motivasyonsuzluk durumunun ortadan kaldırılmasıyla rekreatif faaliyetlere katılım düzeyinin artacağını savunmuştur. Fiziksel aktivitelerin kişiye sağlamış olduğu faydalar göz önüne alındığında, serbest zaman aktivitelerine yönelik olarak bireyin sahip olduğu motivasyon düzeyinin ne tür değişkenlerden etkilendiğini bilmek ve buna yönelik stratejiler geliştirmek sadece bireysel fayda açısından değil toplum sağlığı için de önem arz etmektedir. $\mathrm{Bu}$ anlamda araştırmacılar serbest zaman motivasyonunun neyden etkilendiğini ve nasıl şekillendiğini pek çok farklı kurgu ve örneklem ile araştırmalarında defalarca ortaya koymaya çalışmışlardır (Iso-Ahola ve Allen, 1982; Beggs ve Elkins, 2010; Dillard ve Bates, 2011; Gumus ve Isik, 2018; Walker ve ark.,2020).

Ülkemiz son yıllarda tesisleşme adına büyük adımlar atmıştır. $\mathrm{Bu}$ adımlar üniversite kampüsleri içerisinde de kendilerini göstermiştir. Birçok üniversite kampüsünde spor tesisleri olmazsa olmaz bir konumdadır.
Ancak hem şehirde hem de kampüs içerisinde yapılan tesislerin doldurulmasi ve aktif kullanımı ile ilgili olarak hala bazı problemler yaşanmaktadır. Bireylere niçin sportif aktivitelere katılmadıkları sorulduğunda en başta tesis yetersizliğinden bahsetmektedirler (Ekinci ve ark., 2014). Özellikle son yıllarda yapilan tesisler sayesinde sportif ve rekreatif aktivitelere katılımın önünde tesis yetersizliği ve ulaşılabilirlik sorunu çok fazla kalmamıştır. $\mathrm{Bu}$ anlamda düşünmüş olduğumuzda spor yapmanın faydalı olduğunu bilen eğitimli bireyler olan üniversite personelinin kampüs içerisindeki sportif tesisler hakkında bilgi sahibi olup olmadığını bilmemiz, etkinliklere katılımları hakkında bilgi sahibi olmamız, tesislerden ne kadar faydalanip faydalanmadıklarını öğrenmemiz sportif alanların aktif kullanılabilirliğini anlamamız ve yeni stratejiler geliştirmemiz noktasında önem arz etmektedir. Ayrıca tesislere yakın olan üniversite personelleri arasinda hangi farklılıklardan dolayı sportif etkinliklere katılımda motive olduklarını anlamamızda, rekreatif etkinliklere katılmayan bireylerin bu etkinliklere yönlendirmemiz açısından önemlidir. Bu anlamda bu araştırmanın amacı; üniversitedeki spor tesislerinde sportif rekreasyon faaliyetlerine katılan ve katılmayan akademik ve idari personellerin serbest zaman motivasyonlarının farklı değişkenler çerçevesinde incelenmesi olarak belirlenmiştir.

\section{YÖNTEM}

\section{Araştırma Modeli ve Protokol}

$\mathrm{Bu}$ araştırma, nitel araştırma yöntemlerinden tarama modeli ile yapılmıştır. Tarama modeli tavırları, davranışları karşılaştırmak ve betimlemek için bir veri toplama sistemidir (Gürsakal, 2001). Araştırmanın uygulanma evresine geçilmeden önce kişi ve kurumların onayı alınmıştır. Araştırmaya, Recep Tayyip Erdoğan Üniversitesi Girişimsel Olmayan Klinik Araștırmalar Etik Kurulunun 40465587181 say1lı yazıs1 ve 215 numaralı protokol numaras1 ile etik kurul raporu alınarak başlanmıştır. Ardından iki kısımdan oluşan ölçeklerimiz örneklemde belirtilen akademik ve idari personellerin makamlarına gidilerek 
Telci İ. \& Işık U. (2021). Investigation of Leisure Time Motivation of Academic and Administrative Staff Who Do and Do not Participate in Sports Recreation Activities in Sports Facilities of the University. International Journal of Recreation and Sport Science, 5(1); 51-62.

çalışmanın gayesi ve içeriği anlatılarak ölçeklerin tam olarak doldurulması istenmiştir.

\section{Katılımclar}

Çalışmanın evrenini Rize Recep Tayyip Erdoğan Üniversitesinde çalışan akademik ve idari personeller oluşturmaktadır. Çalışmanın örneklem grubunu ise raslantısal seçilen ve çalışmada istekli olarak yer alan Recep Tayyip Erdoğan Üniversitesinin sportif tesislerinin herhangi birisinden en 1 defa yararlanmış veya hiç yararlanmamış olan 176 akademik ve 142 idari personel olmak üzere toplamda 318 personel $($ Xyaş $=34.27 \pm 5.84)$ oluşturmaktadır.

\section{Veri Toplama Tekniği}

Araştırmanın amacina ulaşabilmesi araştırmacılar tarafından hazırlanmış kişisel bilgi formu ve serbest zaman motivasyon ölçeği kullanılmıştır. Veriler 2019-2020 Eğitim-Öğretim y1lı içerisinde toplanmıştır.

Kişisel Bilgi Formu: Katılımcılar yaş, cinsiyet, medeni durum, idari veya akademik görevi, ünvanı, memuriyetteki toplam yıl1, kurumdaki toplam çalışma yılı, gelir düzeyi, serbest zaman süresi, sportif rekreasyon alanları hakkında bilgi düzeyi, sportif rekreasyon alanlarından faydalanma durumları, serbest zaman değerlendirme düzeyleri, haftalık serbest zaman süreleri, serbest zamanları değerlendirmede zorluk çekme değişkenleri gibi bilgileri edinmeye yönelik kişisel bilgi formunu kağıt kalem kullanarak doldurmuşlardır.

Serbest Zaman Motivasyon Ölçeği: Pellettier vd., (1996) Deci ve Ryan (1985)' in serbest zamana yönelik motivasyon teorisinden yola çıkarak bireylerin serbest zaman motivasyon düzeylerini ölçmeyi amaçlamış ve bu doğrultuda yeni bir ölçüm aracı geliştirmiştir. Ölçek, bireyleri rekreasyonel egzersizlere katılıma motive edebilecek faktörleri içeren "bilmek" (içsel motivasyon), "başarmak" (içsel motivasyon), "uyaran yaşama" (içsel motivasyon), "içe atım" (dışsal motivasyon), "özdeşim" (dışsal motivasyon), "dışsal düzenleyen" (dişsal motivasyon) ve "motivasyonsuzluk" gibi 7 alt boyut ve toplam 28 maddeden oluşmaktadır. Ölçeğin Türkçe güvenirliği ve geçerliği "Mutlu" tarafından,
2008 yılında yapılmıştır. Ölçeğin Türkçe formu, toplam 22 maddeden ve (1) motivasyonsuzluk (2) bilmek ve başarmak, (3) uyaran yaşama, (4) özdeşim/ içe atım ve (5) dışsal düzenleme olmak üzere 5 alt boyuttan oluşmaktadır. Bu çalışmada 5 alt boyutlu yapı kullanılmış ve ölçeğin alt boyutlarına ilişkin iç tutarlılik katsayıları $\quad 60$ ile $\quad .73$ arasında değiştiği tespit edilmiştir.

\section{Verilerin Analizi}

Verilerin genel özelliklerini belirlemede tanımlayıcı istatistik, frekans ve yüzde dağılımlar yapılmıştır. İstatistik testler olarak öncelikle katılımcıların tüm demografik bilgilerine ayrı ayrı normallik testleri (Kolmogorov Simirnov ve Saphiro Wilk) uygulanmıştır. Ayrıca tüm alt boyutların çarpıklık ve basıklık katsayılarına da bakılmıştır. Hem çarpıklık basıklık katsayıları hem de normallik testleri verilerin normal dağılmadığı yönünde kanıtlar ortaya koymuştur (Büyüköztürk ve ark., 2017). Normal dağılıma sahip olmayan verilere ikili karşılaştırmalar için Mann Whitney U ve 3 ve üzeri grup karşılaştırmalarda ise Kruskal Wallis testi uygulanmıştır. Krusal-Wallis- $\mathrm{H}$ testinin ardından gruplar arasında herhangi bir anlamlı bir farkın bulunup bulunmadığını tespit etmek için Pairwise Comparisons karşılaştırmaları kullanıldı. Bonferroni düzeltmesi kullanılarak tüm farkların anlamlılık düzeyleri yeniden hesaplanarak sonuçlar buna göre rapor edilmiştir.

\section{BULGULAR}

Tablo 1. Katılımciların \%61.9'u evli iken \%38.1'i bekardır. Katılımcıların \%55.3'ü akademik personellerden oluşmaktadır. Ayrıca katılımcıların büyük bir oranı kampüs içerisindeki sportif rekreasyon alanları hakkında bilgi sahibi iken; yine büyük bir çoğunlupu bu alanlarda "ara sıra" faydalandıklarını belirtmişlerdir. 
Telci İ. \& Işı1k U. (2021). Investigation of Leisure Time Motivation of Academic and Administrative Staff Who Do and Do not Participate in Sports Recreation Activities in Sports Facilities of the University. International Journal of Recreation and Sport Science, 5(1); 51-62.

Tablo 1: Bazı değişkenler açısından tanımlayıcı istatistik sonuçları $(\mathrm{n}=318)$

\begin{tabular}{|c|c|c|c|c|}
\hline & Tümü (\%) & Erkek (\%) & Kadın (\%) & $p$-value \\
\hline \multicolumn{5}{|l|}{ Medeni Durum } \\
\hline Evli & 61.9 & 63.5 & 59.5 & \multirow{2}{*}{0.481} \\
\hline Bekâr & 38.1 & 36.5 & 40.5 & \\
\hline \multicolumn{5}{|l|}{ Görev } \\
\hline İdari & 44.7 & 46.7 & 41.3 & \multirow{2}{*}{0.349} \\
\hline Akademik & 55.3 & 53.3 & 58.7 & \\
\hline \multicolumn{5}{|l|}{ Memuriyetteki Toplam Çalışma Süresi } \\
\hline $1-5$ Y 11 & 36.5 & 31.0 & 45.5 & \multirow{3}{*}{0.021} \\
\hline 6-10 Y1l & 47.2 & 49.7 & 43.0 & \\
\hline 11 Y1l ve Üzeri & 16.4 & 19.3 & 11.6 & \\
\hline \multicolumn{5}{|l|}{ Gelir Durumu } \\
\hline $2501-4000$ & 13.5 & 14.2 & 12.4 & \multirow{5}{*}{.834} \\
\hline $4001-5500$ & 23.9 & 24.4 & 23.1 & \\
\hline $5501-7000$ & 35.5 & 36.5 & 33.9 & \\
\hline $7001-8500$ & 17.6 & 15.7 & 20.7 & \\
\hline 8501 ve üstü & 9.4 & 9.1 & 9.9 & \\
\hline \multicolumn{5}{|l|}{ Sportif Rekreasyon Alanları Bilgi Düzeyi } \\
\hline Tamamı Hakkında Bilgim Var & 19.5 & 21.8 & 15.7 & \multirow{3}{*}{0.171} \\
\hline Bir Kısmı Hakkında Bilgim Var & 77.4 & 74.1 & 82.6 & \\
\hline Hiçbirinden Haberdar Değilim & 3.1 & 4.1 & 1.7 & \\
\hline \multicolumn{5}{|l|}{ Alanlardan Faydalanma Sıklığı } \\
\hline Siklıkla & 2.5 & 3.6 & 0.8 & \multirow{2}{*}{0.000} \\
\hline Ara Sira & 73.0 & 82.7 & 57.0 & \\
\hline Hiç Faydalanmadım & 24.5 & 13.7 & 42.1 & \\
\hline \multicolumn{5}{|c|}{ Serbest Zamanları Genel Olarak Nasıl Değerlendirildiği } \\
\hline Ev içi aktiviteler & 25.2 & 17.3 & 38.0 & \multirow{4}{*}{0.000} \\
\hline Sportif Aktiviteler & 40.6 & 56.9 & 14.0 & \\
\hline Kültürel ve Sanatsal & 14.8 & 9.6 & 23.1 & \\
\hline Doğada Yapılan Etkinlikler & 19.5 & 16.2 & 24.8 & \\
\hline \multicolumn{5}{|l|}{ Haftalık Serbest Zaman Süresi } \\
\hline 10 saat ve alt1 & 11.3 & 9.6 & 14.0 & \multirow{5}{*}{0.208} \\
\hline $11-15$ saat & 7.5 & 7.6 & 7.4 & \\
\hline 16-20 saat & 10.1 & 10.2 & 9.9 & \\
\hline $21-25$ saat & 46.9 & 44.2 & 51.2 & \\
\hline 26 saat ve üstü & 24.2 & 28.4 & 17.4 & \\
\hline
\end{tabular}

${ }^{\mathrm{a} C h i-s q u a r e ~ t e s t . ~}$

Tablo 2'de katılımciların cinsiyet, medeni durum ve görev değişkenleri açısından serbest zaman motivasyonlarına ilişkin karşılaştırmalar yer almaktadır.
Buna göre katılımcıların cinsiyetleri açısından serbest zaman motivasyonu ölçeği alt boyutlarında herhangi anlamlı bir farklılığa rastlanmamıştır $(p>0,05)$. Medeni durum ve görev değişkenleri açısından baktığımızda ise motivasyonsuzluk alt boyutu haricindeki diğer 
Telci İ. \& Işı1k U. (2021). Investigation of Leisure Time Motivation of Academic and Administrative Staff Who Do and Do not Participate in Sports Recreation Activities in Sports Facilities of the University. International Journal of Recreation and Sport Science, 5(1); 51-62.

alt boyutlarda anlamlı farkliliklara rastlanmıştır $(\mathrm{p}<0,05)$. Bekar katılımcıların uyaran yaşama, bilme-başarma, özdeşim/içe atma alt boyutlarındaki sira ortalamaları evli katılımciların sira ortalamalarından anlamlı şekilde daha yüksek iken; dişsal düzenleme alt boyutunda evli katılımciların sira ortalamaları bekar katılımciların sira ortalamalarından anlamlı şekilde daha yüksek bulunmuştur. Akademik personelin yine uyaran yaşama, bilme-başarma, özdeşim/içe atma alt boyutlarındaki sıra ortalamaları idari personelin sira ortalamalarından anlaml şekilde daha yüksek iken; dışsal düzenleme alt boyutunda idari personelin sira ortalamaları akademik personelin sira ortalamalarından anlamlı şekilde daha yüksek bulunmuştur.

Tablo 2. Mann Whitney-U Testi Sonuçları

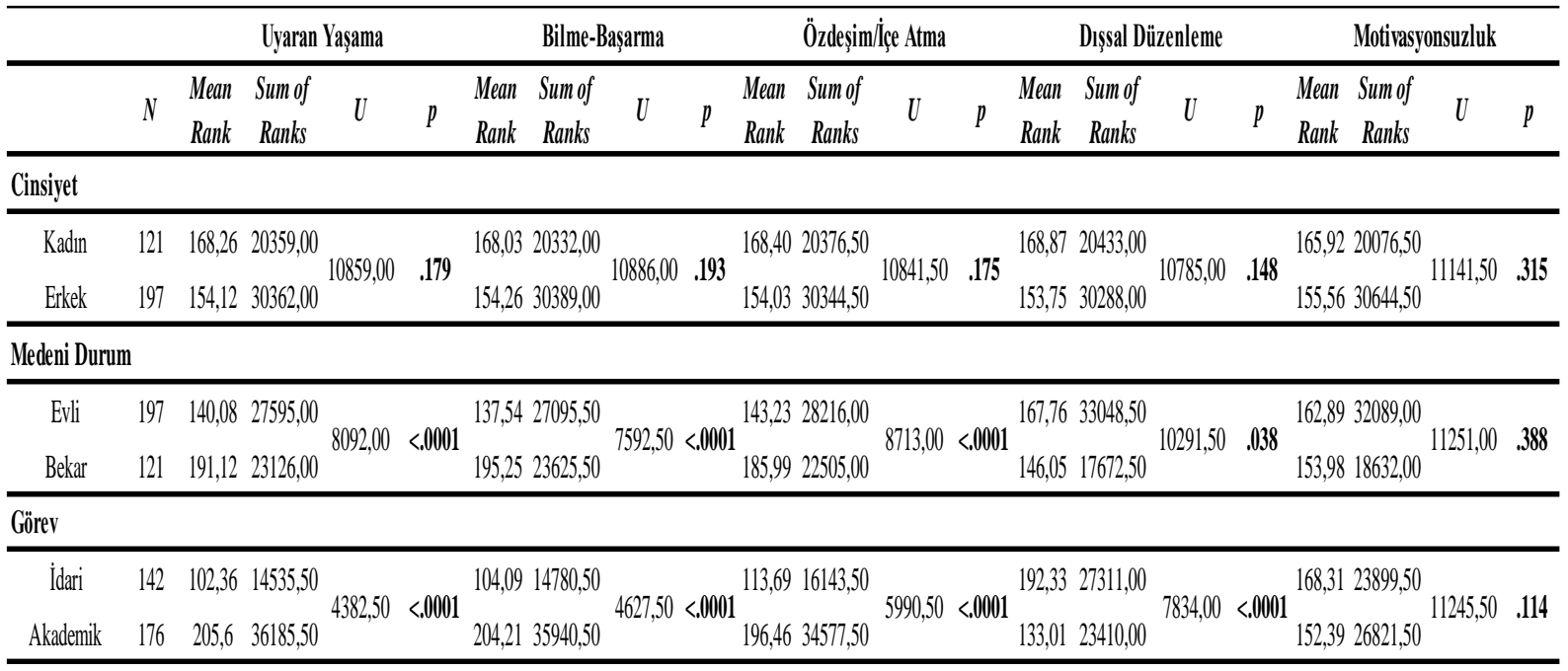

Tablo 3'de katılımciların memuriyetteki toplam çalışma süresi, gelir durumu, kampüs içerisindeki sportif rekreasyon alanları bilgi düzeyi, sportif rekreasyon alanlarından faydalanma sıklığı, serbest zamanları genel

olarak nasıl değerlendirildiği ve haftalık serbest zaman süreleri açısından serbest zaman motivasyonlarına ilişkin karşılaştırmalar yer almaktadır. 
Telci İ. \& Işık U. (2021). Investigation of Leisure Time Motivation of Academic and Administrative Staff Who Do and Do not Participate in Sports Recreation Activities in Sports Facilities of the University. International Journal of Recreation and Sport Science, 5(1); 51-62.

Tablo 3. Kruskal Wallis-H Testi Sonuçları

\begin{tabular}{|c|c|c|c|c|c|c|c|c|c|c|c|c|c|c|c|c|c|c|c|c|c|c|c|c|c|c|}
\hline & \multicolumn{6}{|c|}{ Uyaran Yaşama } & \multicolumn{5}{|c|}{ Bilme-Başarma } & \multicolumn{5}{|c|}{ Özdeşim/Ị̇e Atma } & \multicolumn{5}{|c|}{ Dı̣ssal Düzenleme } & \multicolumn{5}{|c|}{ Motivasyonsuzluk } \\
\hline & $N$ & $\begin{array}{c}\text { Mean } \\
\text { of } \\
\text { Ranks }\end{array}$ & $s d$ & $X^{2}$ & $p$ & $\begin{array}{c}\text { Pairwise } \\
\text { Com. }\end{array}$ & $\begin{array}{l}\text { Mean of } \\
\text { Ranks }\end{array}$ & $s d$ & $X^{2}$ & $p$ & $\begin{array}{l}\text { Pairwise } \\
\text { Com. }\end{array}$ & $\begin{array}{c}\text { Mean } \\
\text { of } \\
\text { Ranks }\end{array}$ & $s d$ & $X^{2}$ & $p$ & $\begin{array}{c}\text { Pairwise } \\
\text { Com. }\end{array}$ & $\begin{array}{c}\text { Mean } \\
\text { of } \\
\text { Ranks }\end{array}$ & sd & $X^{2}$ & $p$ & $\begin{array}{l}\text { Pairwise } \\
\text { Com. }\end{array}$ & $\begin{array}{c}\text { Mean } \\
\text { of } \\
\text { Ranks }\end{array}$ & sd & $X^{2}$ & $p$ & $\begin{array}{l}\text { Pairwise } \\
\text { Com. }\end{array}$ \\
\hline \multicolumn{27}{|c|}{ Memuriyetteki Toplam Çalşşa Süresi } \\
\hline $\begin{array}{c}\text { 1. } 1-5 \text { Yil } \\
\text { 2. } 6-10 \text { Yil } \\
\text { 3. } 11 \text { Yl ve Üstü } \\
\end{array}$ & $\begin{array}{l}116 \\
150 \\
52 \\
\end{array}$ & $\begin{array}{l}171,56 \\
154,08 \\
148,22 \\
\end{array}$ & 2 & 3,364 & 186 & & $\begin{array}{l}175,48 \\
148,16 \\
156,57 \\
\end{array}$ & 2 & 5,87 & .053 & & $\begin{array}{l}163,26 \\
156,49 \\
159,78 \\
\end{array}$ & 2 & .358 & .836 & & $\begin{array}{l}155,31 \\
156,82 \\
176,58 \\
\end{array}$ & 2 & 2,229 & 0.328 & & $\begin{array}{l}154,22 \\
158,88 \\
173,08 \\
\end{array}$ & 2 & 1,616 & .446 & \\
\hline \multicolumn{27}{|l|}{ Gelir } \\
\hline $\begin{array}{c}1.2501-4000 \\
2.4001-5500 \\
3.5501-7000 \\
4.7001-8500 \\
5.8501 \text { ve üstü } \\
\end{array}$ & $\begin{array}{r}43 \\
76 \\
113 \\
56 \\
30 \\
\end{array}$ & $\begin{aligned} 87,37 \\
164,51 \\
162,68 \\
181,56 \\
197,02 \\
\end{aligned}$ & 4 & 35,714 & $<.0001$ & $\begin{array}{l}2>1 \\
3>1 \\
4>1 \\
5>1\end{array}$ & $\begin{array}{l}110,24 \\
162,82 \\
164,58 \\
167,80 \\
187,03 \\
\end{array}$ & 4 & 16,02 & $<.0001$ & $\begin{array}{l}3>1 \\
5>1\end{array}$ & $\begin{array}{l}106,37 \\
156,13 \\
167,77 \\
169,91 \\
193,58 \\
\end{array}$ & 4 & 20,353 & $<.0001$ & $\begin{array}{l}3>1 \\
4>1 \\
5>1\end{array}$ & $\begin{array}{l}203,33 \\
154,68 \\
153,17 \\
142,02 \\
165,35 \\
\end{array}$ & 4 & 13,049 & 0.011 & $1>4$ & $\begin{array}{l}175,24 \\
156,03 \\
152,95 \\
158,84 \\
171,62 \\
\end{array}$ & 4 & 2,615 & .624 & \\
\hline \multicolumn{27}{|c|}{ Sportif Rekreasyon Alanlan Bilgi Düzeyi } \\
\hline $\begin{array}{l}\text { 1. Tamamı Hakknnda Bilgim Var } \\
\text { 2. Bir Kısmı Hakknnda Bilgim Var } \\
\text { 3. Hiçbirinden Haberdar Değlimm } \\
\end{array}$ & $\begin{array}{c}62 \\
246 \\
10 \\
\end{array}$ & $\begin{array}{l}122,06 \\
173,05 \\
58,25 \\
\end{array}$ & 2 & 28,286 & $<.0001$ & $\begin{array}{l}2>1 \\
2>3\end{array}$ & $\begin{array}{r}131,6 \\
170,92 \\
51,55 \\
\end{array}$ & 2 & 23,414 & $<.0001$ & $\begin{array}{l}2>1 \\
2>3\end{array}$ & $\begin{array}{c}139,06 \\
169,28 \\
45,7 \\
\end{array}$ & 2 & 21,311 & $<.0001$ & $\begin{array}{l}2>3 \\
1>3\end{array}$ & $\begin{array}{l}180,16 \\
152,38 \\
206,45 \\
\end{array}$ & 2 & 7,434 & 0.024 & & $\begin{array}{l}159,34 \\
156,65 \\
230,65 \\
\end{array}$ & 2 & 6,602 & 0.037 & \\
\hline \multicolumn{27}{|c|}{ Sportif Rekreasyon Alanlardan Faydalanama Ssklığı } \\
\hline $\begin{array}{c}\text { 1. Skklkla } \\
\text { 2. Ara Sira } \\
\text { 3. Hiç Faydalanmadm }\end{array}$ & $\begin{array}{c}8 \\
232 \\
78 \\
\end{array}$ & $\begin{array}{c}135,5 \\
170,12 \\
130,38\end{array}$ & 2 & 11,684 & .003 & $2>3$ & $\begin{array}{l}159,25 \\
167,05 \\
137,08\end{array}$ & 2 & 6,237 & 0.044 & & $\begin{array}{l}169,75 \\
165,22 \\
141,44\end{array}$ & 2 & 4,033 & .133 & & $\begin{array}{l}145,06 \\
150,61 \\
187,42\end{array}$ & 2 & 9,855 & .007 & $2>3$ & $\begin{array}{l}87,25 \\
155,72 \\
178,15\end{array}$ & 2 & 9,057 & .011 & \\
\hline \multicolumn{27}{|c|}{ Serbest Zamanlan Genel Olarak Nasıl Değerlendirildiği } \\
\hline $\begin{array}{l}\text { 1. Ev içi Aktivitelerle } \\
\text { 2. Sportif Aktivitelerle } \\
\text { 3. Külturel ve Sanatsal } \\
\text { 4. Doğada Yapplan Etkinlikler } \\
\end{array}$ & $\begin{array}{c}80 \\
129 \\
47 \\
62 \\
\end{array}$ & $\begin{array}{l}103,79 \\
188,21 \\
166,07 \\
166,65 \\
\end{array}$ & 3 & 43,378 & $<.0001$ & $\begin{array}{l}2>1 \\
3>1 \\
4>1\end{array}$ & $\begin{array}{l}103,15 \\
184,98 \\
168,26 \\
172,56 \\
\end{array}$ & 3 & 41,862 & $<.0001$ & $\begin{array}{l}2>1 \\
3>1 \\
4>1\end{array}$ & $\begin{array}{l}116,46 \\
178,12 \\
168,31 \\
169,61 \\
\end{array}$ & 3 & 24,164 & $<.0001$ & $\begin{array}{l}2>1 \\
3>1 \\
4>1\end{array}$ & $\begin{array}{l}190,29 \\
126,84 \\
183,38 \\
169,61 \\
\end{array}$ & 3 & 30,062 & $<.0001$ & $\begin{array}{l}1>2 \\
3>2 \\
4>2\end{array}$ & $\begin{array}{l}192,58 \\
138,56 \\
175,61 \\
148,19 \\
\end{array}$ & 3 & 20,601 & $<.0001$ & $1>2$ \\
\hline \multicolumn{27}{|l|}{ Haftallk Serbest Zaman Süresi } \\
\hline $\begin{array}{l}\text { 1. } 10 \text { saat ve daha az } \\
\text { 2. } 11-15 \text { saat } \\
\text { 3. } 16-20 \text { saat } \\
\text { 4. } 21-25 \text { saat } \\
\text { 5. } 26 \text { saat ve üzeri }\end{array}$ & $\begin{array}{c}36 \\
24 \\
32 \\
149 \\
77\end{array}$ & $\begin{array}{r}108,31 \\
105,13 \\
82,52 \\
182,12 \\
188,6\end{array}$ & 4 & 59,848 & $<.0001$ & $\begin{array}{l}4>1 \\
4>2 \\
4>3 \\
5>1 \\
5>2 \\
5>3\end{array}$ & $\begin{array}{l}132,13 \\
147,17 \\
104,22 \\
171,55 \\
175,81\end{array}$ & 4 & 48,132 & $<.0001$ & $\begin{array}{l}4>3 \\
5>3 \\
4>1 \\
5>1\end{array}$ & $\begin{array}{l}132,13 \\
147,17 \\
104,22 \\
171,55 \\
175,81\end{array}$ & 4 & 20,308 & $<.0001$ & $\begin{array}{l}4>3 \\
5>3\end{array}$ & $\begin{array}{l}211,39 \\
240,63 \\
226,11 \\
130,78 \\
137,85\end{array}$ & 4 & 67,779 & $<.0001$ & $\begin{array}{l}1>4 \\
1>5 \\
2>4 \\
2>5 \\
3>4 \\
3>5\end{array}$ & $\begin{array}{l}185,78 \\
166,13 \\
203,08 \\
151,29 \\
142,93\end{array}$ & 4 & 14,787 & $<.0001$ & $3>5$ \\
\hline
\end{tabular}

Ayrıca ortaya çıkan farkların hangi değişkenler arasında olduğu da Tablo 3'de gösterilmektedir. Yapılan analizlere göre katılımcıların memuriyetteki toplam çalışma süreleri açısından herhangi anlamlı farklıliklara rastlanmamıştır $(\mathrm{p}>0,05)$. Katılımcıların gelir durumları açısından ise motivasyonsuzluk alt boyutu hariç diğer tüm alt boyutlarda anlamlı farkl11ıklara rastlanırken; sportif rekreasyon alanları hakkındaki bilgi düzeyleri ile serbest zaman motivasyon ölçeğinin tüm alt boyutları arasinda yine anlamlı farklılıklara rastlanılmıştır $(p<0,05)$. Ancak Bonferroni düzeletmesinden dolayı iki alt boyutta gruplar arasındaki fark rapor edilmemiştir. Katılımciların sportif rekreasyon alanlarından faydalanma sıklıkları ile uyaran yaşama, bilme-başarma, dişsal düzenleme ve motivasyonsuzluk alt boyutları arasinda anlamlı farkl111klar tespit edilirken (Bonferroni düzeltmesinden dolayı iki alt boyutta rapor edilmedi); serbest zamanları genel olarak nasıl değerlendirdikleri ile serbest zaman motivasyonu ölçeğinin tüm alt boyutları arasında anlamlı farklılıklar tespit edilmiştir $(\mathrm{p}<0,05)$. Son olarak katılımciların haftalık serbest zaman süreleri ile serbest zaman motivasyonu ölçeğinin tüm alt boyutları arasında anlamlı farklılıklar tespit edilmiștir $(\mathrm{p}<0,05)$.

\section{TARTIŞMA VE SONUÇ}

Benzer eğitim ve sosyo-ekonomik düzeye sahip, sportif rekreasyon alanlarına ulaşma noktasında herhangi bir güçlük çekmeyen üniversite personelinin serbest zaman motivasyonlarının farklı değişkenler açısından karşılaştırıldığ 1 bu çalışmada, katılımcıların sahip oldukları farklı özelliklerin serbest zaman motivasyonu üzerinde fark yarattığ anlaşılmıştır.

Yapılan analizlere göre cinsiyet değişkeni açısından bütün alt boyutlarda anlamlı bir fark olmamasına rağmen erkek katılımcıların daha yüksek puanlar aldığı görüldü. Literatürde hem kadınların hem de erkeklerin birbirlerine serbest zaman motivasyonları ortalamaları açısından üstünlük sağladığı çalışmaların yanı sıra, herhangi farklılığa rastlanmayan çalışmalara da rastlamak mümkündür. Fortier ve ark. (1995) çalışmasında da kadınların başarma puanlarının erkeklere göre daha yüksek olduğu, motivasyonsuzluğun ise erkeklerde daha yüksek olduğuna ulaşmıştır. Kaya (2003)'nın yaptığı çalışmada da erkeklerin motivasyonsuzlukları kadınlara göre istatistiki olarak anlamlı yüksek olarak 
Telci İ. \& Işık U. (2021). Investigation of Leisure Time Motivation of Academic and Administrative Staff Who Do and Do not Participate in Sports Recreation Activities in Sports Facilities of the University. International Journal of Recreation and Sport Science, 5(1); 51-62.

bulunmuştur. Mutlu (2008), yaptığı çalışmada ise kadınların motivasyonsuzluğu erkeklere göre daha yüksek bulunmuştur. Altunay ve Balcı (2018)'nın yaptıkları farklı bir çalışmada serbest zaman motivasyon ölçeğinde yer alan beş alt boyutun dişsal düzenleme boyutu hariç dört tanesinde kadınların erkeklere göre motivasyonlarının daha yüksek olduğu istatistik olarak anlamlı bulunmuştur. Erkeklerin sadece dişsal düzenleme boyutundaki motivasyon değerlerinin kadınlardan yüksek olduğu ortaya çıkmıştır. Çalışmamızda kadın ve erkek katılımcılar arasında herhangi anlamlı bir fark ortaya çıkmaması üniversite çalışanlarının eğitim düzeylerinin birbirlerine yakın olmasından kaynaklanıyor olabilir. Erkek akademisyenlerin yanında kadın akademisyenlerde serbest zamanlarını aktif bir şekilde değerlendirme eğilimindedirler. Eğitim seviyesinin birbirine yakın olmuş olduğu, sosyo-kültürel yapının birbirine benzer olduğu ortamlarda kadın ve erkek katılımcılar arasında herhangi bir fark ortaya çıkmaması beklenen bir durumdur.

Medeni Durum değişkenini açısından uyaranyaşama, özdeşim-içe atma, bilme ve başarma ve dişsal düzenleme alt boyutlarında anlamlı bir şekilde farklılıklar ortaya çıkmıştır. Yapılan benzer çalışmalarda Mutlu vd., (2011)'nin yaptığg çalışmada, dışsal düzenleme alt boyutunda medeni hal'e göre bekar katılımcıların daha yüksek puanlara sahip olduğu gösterilmektedir. Öğretmenler üzerinde yapılan çalışmada ise medeni durumlar açisında herhangi anlamlı farklilıklara rastlanmamıştır (Altunay ve Balcı, 2018). Evli olan bireylerin önceliği aileleridir. Ancak bekar olan katılımcılar evli olan katılımcılara oranla çok daha fazla serbest zamana sahiptirler ve bu serbest zamanı aktif bir şekilde değerlendirmek için daha rahat bir şekilde motive olabilirler. Evli katılımcılar serbest zamanlarını daha çok aileleri ve çocukları ile geçirdiklerinden ve bu zaman da genel itibari ile bir serbest zaman aktivitesi olarak görülmediğinden evli katılımcıların motivasyonsuzluklarının yüksek olması doğal bir sonuç olarak karşımıza çıkmaktadır.

Görev Durumları değişkenine göre motivasyonsuzluk alt boyutu hariç diğer tüm alt boyutlarda anlamlı farklılıklar ortaya çıkmıştır. Uyaran-yaşama, özdeşim-içe atma ve bilme ve başarma alt boyutlarında anlamlı bir şekilde akademik personel daha yüksek puan alırken; dışsal düzenleme alt boyutunda ise idari personeller anlamlı bir şekilde daha yüksek puanlar elde etmişlerdir. Akademik ve idari personel arasında gelir düzeyi açısından farklılıklar bulunmaktadır. Akademik personellerin ortalama aylik gelirleri idari personelin ortalama aylık gelirlerinden daha yüksektir. $\mathrm{Bu}$ çerçeve de düşünmüş olduğumuzda geliri yüksek olan bireylerin daha yüksek serbest zaman motivasyon düzeylerine sahip olması beklenen bir durumdur. Nitekim Tarcan (2019)'ın yapmış olduğu çalışmada geliri yüksek olan katılımcıların geliri daha düşük olan kat1limcilara oranla bilmek alt boyutunda daha yüksek ortalamalar elde ederken; geliri düşük olan bireylerin yüksek olan bireylere oranla daha yüksek oranda dişsal düzenlemeye sahip oldukları görülmüştür.

Memuriyetteki toplam çalışma süresi değişkenine göre katılımcıların serbest zaman motivasyonlarında herhangi anlamlı bir farkl11ık tespit edilememiştir. Öztaş (2018)'ın yaptığı çalışmada farklı kurumlarda çalışan memurların serbest zaman doyumları arasında kurumlarında çalışma yılları açısından herhangi anlamlı bir farklılığa rastlanmamıştır. Yıldız (2018)'ın emniyet müdürlüğü personeli ile yaptığı farklı bir çalışmada katılımcıların kıdem y1lları ile serbest zaman tutumları arasında herhangi anlamlı bir farkl11ığa rastlanmamıştır. Kamu kurum ve kuruluşlarına giren bireylerin mesleki yılları ve tecrübeleri arttıkça serbest zaman tercihlerinde ve serbest zaman motivasyonların da farklılıklar oluşmamaktadır. Kamu kurumlarında çalışan bireyler ister tecrübeli isterse tecrübesiz olsun serbest zaman aktivitelerine benzer şekilde katılım sağlamaktadır. Farklı görevlerde olan bireyler arasinda her ne kadar farkliliklar oluşsa da kamunun içerisinde ne kadar fazla görev alındığı motivasyonu etkilememiştir.

Gelir Durumu değişkenine göre; uyaranyaşam, özdeşim-içe atma ve bilme ve başarma alt boyutlarında gelir arttıkça anlamlı farklılaşmalar söz konusudur. Motivasyonsuzluk alt boyutunda ise geliri az 
Telci İ. \& Işık U. (2021). Investigation of Leisure Time Motivation of Academic and Administrative Staff Who Do and Do not Participate in Sports Recreation Activities in Sports Facilities of the University. International Journal of Recreation and Sport Science, 5(1); 51-62.

olan katılımcıların ortalamalarının daha yüksek olduğu görülmektedir. Yapılan benzer çalışmalarda Binarbaşı (2006)'nın Kütahya ilinde öğretmenler üzerine yapılan bir çalışmada, öğretmenlerin serbest zaman etkinliklerine yeterli bir şekilde katılamama nedeni olarak ekonomik durumlarını görmedikleri ifade edilmiştir. Ardahan ve Lapa (2010) tarafından yapılan çalışmada da katılımcıların gelir düzeyleri arttıkça bu tür faaliyetlerdeki tatmin düzeylerin de arttığ1 görülmüştür. Mutlu vd., (2011) yaptıkları araştırmaya göre daha düşük gelir düzeyine sahip olan bireylerin daha yüksek motivasyonsuzluk ve dişsal düzenleme puanına sahip oldukları tespit edilmiştir. $\mathrm{Bu}$ sonuçlara bağlı olarak gelir katılımcıların hem serbest zaman tercihlerini hem serbest zamana katılım sıklıklarını dolayısı ile de serbest zaman motivasyonlarını ciddi bir şekilde etkilemektedir. Gelir ne kadar yüksekse serbest zamana katılma noktasında bireyler kendilerini o kadar fazla motive edebilmektedirler.

Kat1lımc1ların sportif rekreasyon alanları hakkındaki bilgi düzeyleri değişkenine göre; Bütün alt boyutlarında anlamlı bir fark tespit edilirken uyaran-yaşama, özdeşim-içe atma ve bilme ve başarma alt boyutlarında "bir kısmı hakkında bilgim var" grubunu oluşturan katılımcılar; dişsal düzenleme ve motivasyonsuzluk alt boyutunda ise "hiç haberdar değilim" grubunu oluşturan katılımcıların daha yüksek puan aldıkları görüldü. Serbest zaman katılımını engelleyen faktörleri araştıran birçok çalışmada ortaya konan ortak nokta katılımciların tesisler hakkındaki sınırlı bilgi düzeyi ve tesislerin yetersizliğidir (Arslan vd.,2018; Tekin vd., 2006; Öz ve Ardahan, 2019; Turan vd., 2019). Rekreatif etkinlikleri gerçekleştirecekleri tesislerin varlığından haberdar olmayanların rekreatif etkinliklere katılım noktasında motivasyonlarının düşük olması beklenen bir durumdur. Ancak serbest zamanlar1 değerlendirmek için hem şehir içinde hem de kampüs içinde yeterli olmasa da bazı tesisler bulunmaktadır. Buralardan haberdar olmanın buraları kullanma noktasinda bireyleri motive edeceği açıktır. Nitekim tesisler hakkında bilgisi olan bireylerin motivasyonları hiç haberdar olmayan katılımcılara göre daha yüksektir. Bireyler tesisler hakkında ne kadar sık bir şekilde bilgilendirilirse o oranda tesis kullanımının artacağı düşünülebilir.

Katılımciların sportif rekreasyon alanlarından faydalanma durumları değişkenine göre; serbest zaman motivasyonları arasında anlamlı farkl11ıklar ortaya çıkmıştır. Buna göre sportif rekreasyon alanlarından faydalanmayan bireylerin motivasyonsuzluklarının yüksek olduğu, faydalanan bireylerin ise motivasyonlarının daha yüksek olduğu görülmüştür. Güngörmüş vd., (2018)'nin yaptıkları çalışmada fiziksel aktiviteye daha çok katılan bireylerin hem serbest zaman doyumlarının hem yaşam doyumlarının hem de serbest zamanda algıladıkları özgürlük düzeylerinin daha fazla olduğu tespit edilmiştir. Ayrıca Öztaş (2018)'in yapmış olduğu farklı bir çalışmada da serbest zaman aktivitesine katılım arttıkça serbest zaman doyumu artmaktadır. Işı ve Güngörmüş (2018)'ün yaptıkları çalışmaya göre ise serbest zaman aktivitelerine katılım arttıkça psikolojik iyi oluşta olumlu değişimler meydana gelmektedir. Serbest zamana katılım olmazsa serbest zamana katılım noktasinda da motivasyon olmaz. Bireylerin serbest zamana katılımları hissettikleri motivasyon sayesinde gerçekleşir ve yaşam doyumunda, serbest zaman doyumunda, psikolojik iyi oluşta, hissedilen özgürlükte artışlar meydana getirir. $\mathrm{Bu}$ anlamda bireylerin etkinliklere duymuş oldukları motivasyon rekreasyon etkinliklerine katılım için öncül şarttır. $\mathrm{Bu}$ şart gerçekleştiğinde de bireyde yukarıda sayılan olumlu psikolojik etkiler ortaya çıkabilir.

Katılımciların serbest zamanlarını değerlendirme değişkenine göre; bütün alt boyutlarında anlamlı bir fark tespit edilirken uyaran-yaşama, özdeşim-içe atma ve bilme ve başarma alt boyutlarında sportif aktivitelere katılan grubun ortalamaları; dişsal düzenleme ve motivasyonsuzluk alt boyutunda ise ev içi aktiviteler yapan grubun ortalamaları daha yüksek bulundu. Yerlisu vd., (2012) yaptıkları çalışmada sportif faaliyetlere katılan katılımciların serbest zaman motivasyonlarında anlamlı farklılıklar ortaya çıkarken; daha pasif etkinliklere katılan bireylerin motivasyonsuzluk puanlarının daha yüksek olduğu görüldü. Lapa ve Ağyar (2012)'ın yaptıkları farklı bir çalışmada sportif 
Telci İ. \& Işı1k U. (2021). Investigation of Leisure Time Motivation of Academic and Administrative Staff Who Do and Do not Participate in Sports Recreation Activities in Sports Facilities of the University. International Journal of Recreation and Sport Science, 5(1); 51-62.

etkinliklere aktif olarak katılan katılımcıların serbest zaman katılımlarında algiladıkları özgürlük düzeylerinin pasif katılımlara oranla daha yüksek olduğu tespit edilmiştir. Bu sonuçlara bağlı olarak sportif etkinliklerin diğer etkinliklere oranla çok daha tatmin edici ve katılıma noktasında bireyleri çok daha fazla motive ettiği söylenebilir. Bireyler sportif etkinliklere diğer etkinliklere katılım sağladıklarından daha fazla bir şekilde katılım sağlamak istemektedirler. Serbest zaman motivasyonu sportif faaliyetler söz konusu olduğunda yüksek ortalamalar elde etmektedir.

Katılımcıların haftalık serbest zaman süreleri değişkenine göre; bütün alt boyutlarında anlamlı bir fark tespit edilirken uyaranyaşama, özdeşim-içe atma ve bilme ve başarma alt boyutlarında 26 saat ve üzeri grubunu oluşturan katılımcılar; dışsal düzenleme ve motivasyonsuzluk alt boyutunda ise 16-20 saat grubunu oluşturan katılımcıların daha ortalamalara sahip olduğu görüldü. Yerlisu vd., (2012)'nin yaptıkları çalışmada katılımciların serbest zaman motivasyon puanlarının aktivitelere katılım sıklığının bireylerin serbest zaman motivasyonlar1 üzerinde fark yarattığ1 tespit edilmiştir. Üstün (2013)'ün yaptığı farklı bir çalışmada örneklem grubunun rekreatif faaliyetlere katılım motivasyonu sahip olunan haftalık serbest zaman süresinden etkilenmekte ve daha fazla serbest zaman süresine sahip olan katılımcıların daha rahat motive oldukları görülmüştür. Güngörmüş vd., (2018)'nin yaptıkları çalışmada haftalık serbest zaman süresi arttıça serbest zaman ilgilenim düzeylerinde de artışlar meydan gelmektedir. Öztaş (2018)'ın yaptığı çalıșma da haftalık serbest zaman süresi arttıkça katılımcıların serbest zaman doyumlarında artışlar meydana gelmiştir. Birey işten arda kalan zamanında serbest zaman aktivitelerine katılmaktadır. Bu durum göz önüne alındığında bireyin ne kadar fazla serbest zamanı varsa o kadar fazla serbest zaman etkinliklerine katılacak ve katılmak için de motive olacağ 1 açıktır.

\section{ÖNERÍLER}

Serbest zamana aktif katılım sağlamak bireyin mutluluğu, yaşam doyumu ve tatmini, psikolojik iyi oluş düzeyine önemli katkılar sağlamaktadır. $\mathrm{Bu}$ anlamda serbest zamana katılım sağlamanın ön şartı olan serbest zamana karşı motive olmak oldukça önem arz etmektedir. Bu çalışma kapsamında eğitim düzeyi belirli bir seviyenin üstünde olan ve düzenli geliri olan katılımcıların serbest zaman motivasyonları incelenmeye çalışılmıştır.

$\mathrm{Bu}$ sonuçlara dayalı olarak şunlar önerilebilir:

-Üniversitedeki akademik ve idari personelin motivasyonlarının artırılması için diğer kamu kurumlarıyla ve işletmelerle iş birliğine giderek, personelin serbest zamana katılımın kolaylaştırılması ve serbest zaman eğitimi konularında destek verebilirler,

-Üniversiteler, akademik ve idari personelin serbest zamanlarını değerlendirebilecekleri tesislerin ve kulüplerin sayısını artırılıp katılımına teşvik edilebilir,

-Yapilan tesisler hakkında üniversite personeli bilgilendirilebilir,

-Serbest zamanların aktif değerlendirme ile ilgili üniversite personellerine eğitimler düzenlenebilir,

-Sportif faaliyetlerin diğer faaliyetlere oranla çok daha etkin ve faydalı olduğunu üniversite personeline yapılacak eğitimler vasıtası ile aktarılabilir,

-Çalışmanın evren ve örneklemi genişletilerek daha fazla üniversite bünyesinde akademik ve idari personele ulaşılabilir.

-Farklı üniversitelerde çalışan personellerle karşılaştırmalar yapılabilir.

\section{KAYNAKLAR}

Abadan, N. (1961). Türk üniversite öğrencilerinin serbest zaman faaliyeti, boş zamanları değerlendirme semineri. Halk Sağlı̆̆ Eğitim Komitesi Yayını, İstanbul.

Altunay, B. R., Balcı, V. (2018). Ankara ili Keçiören ilçesindeki ilköğretim okullarında görev yapan öğretmenlerin boş zaman etkinliklerine katılım motivasyonu, Spor ve Performans Araştırmalarl, Dergisi, DOI: 10.17155/Omuspd.412516. 
Telci İ. \& Işık U. (2021). Investigation of Leisure Time Motivation of Academic and Administrative Staff Who Do and Do not Participate in Sports Recreation Activities in Sports Facilities of the University. International Journal of Recreation and Sport Science, 5(1); 51-62.

Aoyagi, K., Ishii, K., Shibata, A., Arai, H., Fukamachi, H., \& Oka, K. (2020). A qualitative investigation of the factors perceived to influence student motivation for school-based extracurricular sports participation in Japan. International Journal of Adolescence and Youth, 25(1), 624-637.

Ardahan. F., ve Lapa, T. Y. (2010). Üniversite öğrencilerinin serbest zaman tatmin düzeylerinin cinsiyete ve gelire göre incelenmesi. Spor Bilimleri Dergisi, 21(4), 129-136.

Arslan, E., Namlı. A. Y., \& Doğaner, S. (2018). Üniversite öğrencileri neden aktif değiller? katılımsal engeller. Spormetre Beden Ĕgitimi ve Spor Bilimleri Dergisi, 16(4), 140-150.

Beggs, B. A., \& Elkins, D. J. (2010). The influence of leisure motivation on leisure satisfaction. LARNet-The Cyber Journal of Applied Leisure and Recreation Research, (July).

Bender, A. A., Halpin, S. N., Kemp, C. L., \& Perkins, M. M. (2021). Barriers and facilitators to exercise participation among frail older African American assisted living residents. Journal of Applied Gerontology, 40(3), 268-277.

Binarbaşı, S. (2006). İlköğretim okullarında görev yapan öğretmenlerin boş zamanlarını değerlendirme alışkanlıklarının tespiti ve incelenmesi, Yüksek Lisans Tezi, Kütahya.

Büyüköztürk, Ş., Çakmak, E. K., Akgün, Ö. E., Karadeniz, Ş., \& Demirel, F. (2017). Bilimsel araştırma yöntemleri. Pegem Attf Indeksi, 2017, 1-360.

Can, E., \& Gök, S. (2003). Bir rekreasyon faaliyeti olarak-üniversitelerarası müsabakalara katılan sporcu öğrencilerin liderlik davranışlarının (anlayış gösterme boyutunda) karşılaştırılması. Spor Yönetimi ve Bilgi Teknolojileri, 2(1), 23-30.

Deci, E. L., Ryan, R. M. (1985). Intrinsic motivation and self-determination in human behaviour. new york plenum, [AKT: The general causality orientations scale: Self-determination in personality. Journal of Research in Personality. Volume 19, Issue 2, June 1985, Pages 109134.

Deci, E. L., Ryan, R. M. (1991). A motivational approach to self integration in personality. nebraska symposium on motivation. University Of Nebraska Pres, Lincoln.

Dillard, J. E., \& Bates, D. L. (2011). Leisure motivation revisited: why people recreate. Managing Leisure, 16(4), 253268.

Ekinci, N. E., Kalkavan, A., Üstün, Ü. D., \& Gündüz, B. (2014). Üniversite öğrencilerinin sportif ve sportif olmayan rekreatif etkinliklere katılmalarına engel olabilecek unsurların incelenmesi. Sportif Bakış: Spor ve Ĕgitim Bilimleri Dergisi, 1(1), 1-13

Fortier, M. S., Vallerand, R. J., Briere, N. M., Provencher, P. J. (1995). Competitive and recreational sport structures and gender: A test of their relationship with sport motivation. International Journal of Sport Psychology, 26, 24-39.

Gumus, H., \& Isik, O. (2018). The relationship of physical activity level, leisure motivation and quality of life in candidate teachers. International Journal of Progressive Education, 14(5), 22-32.

Güngörmüş, H. A., Işık, U., Demirdöğen, S. (2018). Dans okullarına üye bireylerin serbest zaman ilgilenim düzeyleri ile psikolojik iyi oluş ilişkisi. 16. Uluslararası Spor Bilimleri Kongresi. Antalya. 1520-1529.

Güngörmüş, H. A., Serdar, E., Beşikçi, T., \& Dirilik, Y. (2018). "Fitness merkezlerinden hizmet alan bireylerin serbest zaman doyumu ve psikolojik iyi oluş ilişkisi," Uluslararası Rekreasyon ve Spor Yönetimi Kongresi, Bildiriler Kitapçı̆̆ Bodrum/Muğla, 425-426.

Hsu, R. M. C. S., \& Valentova, J. V. (2020). Motivation for different physical activities: a comparison among sports, exercises, and body/movement practices1. Universidade de São Paulo, Instituto de Psicologia, Department of Experimental Psychology, São Paulo, Brazil. Psicologia USP, Volume 31, e190153. 1-10.

Iso-Ahola, S. E., \& Allen, J. R. (1982). The dynamics of leisure motivation: The effects of outcome on leisure needs. Research Quarterly for Exercise and Sport, 53(2), 141-149.

Işık, U. (2018). How to be a serious leisure participant? (a case study). Journal of Education and Training Studies, 6(9), 146151.

Işı1k, U., ve Üstün, Ü. D. (2019). Boş zamanları değerlendirmede güncel konular. Son çă̆ Matbaacilık, 978-605-258-775-1

Iş1k, U., ve Güngörmüş, H. A. (2018). Rekreasyonel amaçlı kayak yapan bireylerde serbest zaman doyumu ve psikolojik iyi oluş. 16. Uluslararası Spor Bilimleri Kongresi. Antalya. 1530-1539. 
Telci İ. \& Işık U. (2021). Investigation of Leisure Time Motivation of Academic and Administrative Staff Who Do and Do not Participate in Sports Recreation Activities in Sports Facilities of the University. International Journal of Recreation and Sport Science, 5(1); 51-62.

Işık, U., Görgülü, R., \& Tok, S. (2019). Spor ve egzersiz psikolojisinde gelecek yıllardaki muhtemel değişimler. Presented At The 17th International Sport Sciences Congre.

Kaya, S. (2003). Yetiştirme yurtlarında kalan gençlerin boş zaman değerlendirme eğilimi ve etkinliklerin sosyalleşmeye etkisi, Doktora Tezi. Gazi Üniversitesi, Sağlık Bilimleri Enstitüsü, Beden Eğitimi ve Spor Anabilim Dalı, Ankara.

Kılıç, M. \& Öztürk, E. (2011). Yükseköğretim çerçevesinde öğrenci konseylerinin fonksiyonalist-çatışmacı yaklaşımlar açısından değerlendirilmesi. Uluslararası Yükseköğretim Kongresi: Yeni Yönelişler ve Sorunlar (UYK-2011), 3(14), 20972103.

Kocaekşi, S. (2012). Boş Zaman ve rekreasyon yönetimi. (Ed.), Eskişehir: Anadolu Üniversitesi Yayını, No: 2497, Açıöğretim Fakültesi Yayını No: 1468, Mayıs.

Lapa, T. Y., \& Ağyar, E. (2012). Üniversite öğrencilerinin serbest zaman katılımlarına göre algılanan özgürlük. Spor Bilimleri Dergisi, 23(1), 24-33.

McLean, D. D., Hurd, A. R., \& Rogers, N., B. (2005). Leisure and recreation in modern society. Johns and Bartlett Publishers. Massachusetts.

Mutlu, İ. (2008). Egzersiz yapan kişilerin boş zamanlarına yönelik tutumları üzerine bir araştırma (Kayseri İli Örneği), Yayınlanmamış Yüksek Lisans Tezi, Niğde Üniversitesi Sosyal Bilimler Enstitüsü.

Mutlu. İ., Yılmaz, B., Sevindi, T., Göngörmüş, H. A., Gürbüz, B. (2011). Bireyleri rekreasyonel amaçlı egzersize motive eden faktörlerin çeşitli değişkenlere göre karşılaştırılması. Selçuk Üniversitesi. Beden Eğitimi ve Spor Bilim Dergisi, 13 (1), 54-61.

Öz, N. D., \& Ardahan, F. (2019). Köyde rekreasyon engelleri ölçeği geçerlilik ve güvenirlilik çalışması. Mediterranean Journal of Humanities, 9(1), 141-151.

Özdağ, S. (1996). Yerel yönetimlerde (belediyelerde) rekreatif etkinliklerin yeri ve önemi. Yüksek Lisans Tezi, Gazi Üniversitesi, Sağlık Bilimleri Enstitüsü, Ankara, s:131.

Öztaş, İ. (2018). Farklı kurumlarda çalışan memurların serbest zaman doyum ve mutluluk düzeylerinin belirlenmesi (Kırıkkale ili örneği) (Master's thesis, Ağrı İbrahim Çeçen Üniversitesi, Sosyal Bilimler Enstitüsü).
Pelletier, L. G., Vallerand, R. J., Blais, M. R., Brière, M. N. (1991). Leisure Motivation Scale (LMS-28). [Online Erişim Adresi: http://www.er.uqam.ca/nobel/r26710/LRCS / echelles/EML28_en.pdf].

Pelletier, L. G., Vallerand, R. J., Demers, G. I., Blais, M. R., Brière, M. N. (1996). Vers une conceptualisation motivationnelle nultidimensionnelle du loisir: construction et validation de lechelle de motivation vis a vis des lousirs (eml). Society and Leisure, 19(2), 559-585.

Sáez, I., Solabarrieta, J., \& Rubio, I. (2021). Motivation for physical activity in university students and its relation with gender, Amount of activities, and sport satisfaction. Sustainability, 13(6), 3183.

Smith-Turchyn, J., Allen, L., Dart, J., Lavigne, D., Rooprai, S., Dempster, H., \& Adams, S. C. (2021). Characterizing the exercise behaviour, preferences, barriers, and facilitators of cancer survivors in a rural canadian community: A cross-sectional survey. Current Oncology, 28(4), 31723187.

Tekin, A., Tekin, G., Amman, M. T. (2006). Serbest zamanlarda yapilan fiziksel egzersizin üniversite öğrencilerinin depresyon ve atılganlık düzeylerine etkisi. 9. Uluslararast Spor Bilimleri Kongresi Bildiri Kitapçı̆̆ı , 19-23, Muğla.

Tolukan, E., (2010). Özel yetenekle ilgili bölümlerde okuyan üniversite öğrencilerinin rekreasyonel aktivitelere katılımlarına engel olabilecek unsurların belirlenmesi. Niğde Üniversitesi, Sosyal Bilimler Enstitüsü. (Yayınlanmamış Yüksek Lisans Tezi) Niğde.

Turan, E. B., Gülşen, D. B. A., Bilaloğlu, M. (2019). Kadın Çalışanların Yaşam Doyumu Ile Boş Zaman Engelleri Arasındaki Ilişki: Akdeniz Üniversitesi Örneği. Gaziantep Üniversitesi, Spor Bilimleri Dergisi. 4(1), s: 104-114.

Üstün, Ü. D., Kalkavan, A., Demirel, M. (2013). Investigating free time motivation scores of physical education and faculty of education students according to different variables. TOJRAS 2 (1).

Walker, G. J., Yan, N., \& Kono, S. (2020). Basic psychological need satisfaction and intrinsic motivation during leisure: A crosscultural comparison. Journal of Leisure Research, 51(4), 489-510.

Yerlisu, L. T., Ağyar, E., \& Bahadır, Z. (2012). Yaşam tatmini, serbest zaman motivasyonu, serbest zaman katılımı: 
Telci İ. \& Işık U. (2021). Investigation of Leisure Time Motivation of Academic and Administrative Staff Who Do and Do not Participate in Sports Recreation Activities in Sports Facilities of the University. International Journal of Recreation and Sport Science, 5(1); 51-62.

Beden eğitimi ve spor öğretmenleri üzerine bir inceleme (Kayseri ili örneği). Spormetre Beden Eğitimi ve Spor Bilimleri Dergisi, 10(2), 53-59.

Yıldız, R. (2018). Rekreasyonel aktivitelere katılım durumuna göre bel ve/veya sırt ağrısı çeken bireylerin fizik tedavi alma sıklıkları: Batman ili örneği (Master's thesis, Batman Üniversitesi). 